Article

\title{
Reverse Water Gas Shift by Chemical Looping with Iron-Substituted Hexaaluminate Catalysts
}

\author{
Natalie Utsis, Miron V. Landau * D , Alexander Erenburg and Moti Herskowitz \\ Chemical Engineering Department Blechner Center for Industrial Catalysis and Process Development, \\ Ben-Gurion University of the Negev, Beer-Sheva 84105, Israel; natsad@gmail.com (N.U.); \\ erenburga@gmail.com (A.E.); herskow@bgu.ac.il (M.H.) \\ * Correspondence: mlandau@bgu.ac.il; Tel.: +972-523810233
}

Received: 24 August 2020; Accepted: 16 September 2020; Published: 18 September 2020

check for updates

\begin{abstract}
The Fe-substituted Ba-hexaaluminates (BaFeHAl) are active catalysts for reverse water-gas shift (RWGS) reaction conducted in chemical looping mode. Increasing of the degree of substitution of $\mathrm{Al}^{3+}$ for $\mathrm{Fe}^{3+}$ ions in co-precipitated $\mathrm{BaHAl}$ from $60 \%$ (BaFeHAl) to $100 \%$ (BaFe-hexaferrite, $\mathrm{BaFeHF}$ ), growing its surface area from 5 to $30 \mathrm{~m}^{2} / \mathrm{g}$, and promotion with potassium increased the $\mathrm{CO}$ capacity in isothermal RWGS-CL runs at $350-450{ }^{\circ} \mathrm{C}$, where the hexaaluminate/hexaferrite structure is stable. Increasing $\mathrm{H}_{2}$-reduction temperature converts $\mathrm{BaFeHAl}$ to a thermally stable BaFeHF modification that contains additional Ba-O-Fe bridges in its structure, reinforcing the connection between alternatively stacked spinel blocks. This material displayed the highest $\mathrm{CO}$ capacity of $400 \mu \mathrm{mol} / \mathrm{g}$ at isothermal RWGS-CL run conducted at $550^{\circ} \mathrm{C}$ due to increased concentration of oxygen vacancies reflected by greater surface $\mathrm{Fe}^{2+} / \mathrm{Fe}^{3+}$ ratio detected by XPS. The results demonstrate direct connection between CO capacity measured in RWGS-CL experiments and calculated $\mathrm{CO}_{2}$ conversion.
\end{abstract}

Keywords: hexaaluminate; iron; reverse water gas shift; carbon dioxide; carbon oxide; chemical looping

\section{Introduction}

$\mathrm{CO}_{2}$ can be converted to syngas, a key intermediate in production of green chemicals and fuels [1,2], by reverse water-gas shift (RWGS). Catalysts for this reaction are $\mathrm{Cu}, \mathrm{Ce}, \mathrm{Ni}$, Fe-based oxides as well as supported noble metals ( $\mathrm{Pt}, \mathrm{Rh})$, and multicomponent metal oxides [1-6]. The reaction is reversible and endothermic, thus it yields relatively low conversion at equilibrium at $<600{ }^{\circ} \mathrm{C}$. The shortcoming of those catalysts is significant methanation activity reducing the yield of carbon oxide at high temperatures [6].

Chemical looping (CL) combined two separate steps: hydrogen reduction of metal oxide catalyst followed by $\mathrm{CO}_{2}$ oxidation of the catalyst to produce $\mathrm{CO}$ (Scheme 1). Each one of the two catalytic steps is not thermodynamically limited, thus complete conversion of $\mathrm{CO}_{2}$ can be accomplished at relatively low temperature. Furthermore, since $\mathrm{CO}$ and $\mathrm{H}_{2}$ are not present simultaneously on the catalyst surface, no methanation is expected. Metal oxide catalytic materials suitable for RWGS-CL should have the ability to eliminate oxygen from materials surface for efficient splitting of $\mathrm{C}-\mathrm{O}$ bond of $\mathrm{CO}_{2}$ during adsorption on O-vacancies at surface of the catalyst. It is important to maximize the surface area and surface concentration of suitable $\mathrm{O}$-vacancies governed by cationic environment of precursor oxygen ions.

Iron oxides display natural abundance and high re-oxidation capacity with $\mathrm{CO}_{2}$ over a wide range of operating conditions [7-9]. However, pure iron oxides tend to deactivate rapidly. The major factor for deactivation of pure iron oxide materials is sintering $[10,11]$. To overcome this problem, iron oxides are often modified with other oxide materials such as $\mathrm{CeO}_{2}, \mathrm{MgO}, \mathrm{TiO}_{2}, \mathrm{ZrO}_{2}$, or deposited on $\mathrm{SiO}_{2}$ or 
$\mathrm{Al}_{2} \mathrm{O}_{3}$ [12-16]. The challenge is the formation of mixed oxide phases displaying high performance in CL [17].
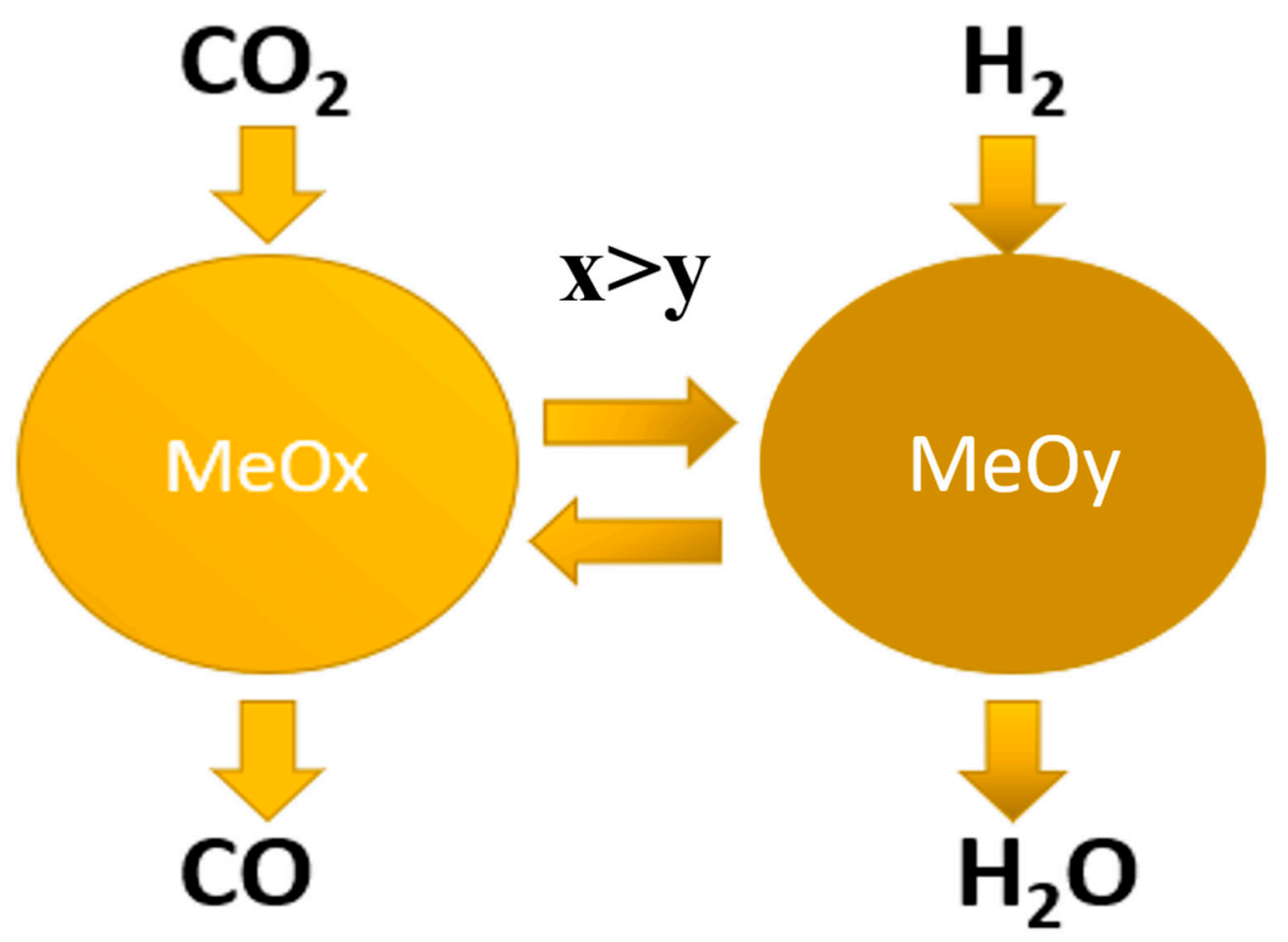

Scheme 1. Principal scheme of reverse water-gas shift chemical looping (RWGS-CL) process.

RWGS-CL with iron-based catalysts was intensively studied over the past few years [17-29], including mixed oxides of perovskite type, supported iron oxides, and Fe-containing mixed oxides solid solutions. Ternary ferrites of spinel structure were also studied [30]. Recently, Kuhn et al. [18-20,24] published a series of studies of RWGS-CL on various bulk and supported perovskites. $\mathrm{La}_{1-x} \mathrm{Sr}_{x} \mathrm{CoO}_{3}$ [18], $\mathrm{La}_{0.75} \mathrm{Sr}_{0.25} \mathrm{Co}_{(1-y)} \mathrm{Fe}_{y} \mathrm{O}_{3}$ [19], $\mathrm{La}_{0.75} \mathrm{Sr}_{0.25} \mathrm{FeO}_{3}$ (LSF) supported on $\mathrm{SiO}_{2}$ and $\mathrm{SiC}$ [20] and other supports [24] and $\mathrm{A} 1_{1-x} \mathrm{~A}_{2} \mathrm{~B}_{(1-y)} \mathrm{B}_{y} \mathrm{O}_{3}(\mathrm{~A} 1 \equiv \mathrm{La} ; \mathrm{A} 2 \equiv \mathrm{Sr}, \mathrm{Ca}, \mathrm{Ba} ; \mathrm{B} 1, \mathrm{~B} 2 \equiv \mathrm{Fe}, \mathrm{Cr}, \mathrm{Al}, \mathrm{Mn}$, Co) [21] were synthesized and characterized. $\mathrm{La}_{0.75} \mathrm{Sr}_{0.25} \mathrm{FeO}_{3}$ (LSF) displayed at $550{ }^{\circ} \mathrm{C}$ a similar rate of $\mathrm{CO}$ formation (about $70 \mu \mathrm{mol} \mathrm{CO}$ g perovskite ${ }^{-1} \mathrm{~min}^{-1}$ ) as $\mathrm{La}_{1-x} \mathrm{Sr}_{x} \mathrm{CoO}_{3}$ at $850{ }^{\circ} \mathrm{C}$. The vacancy formation energy, considered as the most significant parameter in RWGS-CL, was calculated using Density Functional Theory (DFT) for 14 perovskite compositions [21]. Their CO capacity was measured at $550{ }^{\circ} \mathrm{C}$ [21]. Five cycles conducted with one of the perovskites $\left(\mathrm{La}_{0.6} \mathrm{Ca}_{0.4} \mathrm{Fe}_{0.4} \mathrm{Mn}_{0.6} \mathrm{O}_{3}\right)$ produced a relatively constant $\mathrm{CO}$ capacity of about $400 \mu \mathrm{mol} \mathrm{CO} \mathrm{g}{ }^{-1}$. The $\mathrm{CO}_{2}$ conversion for all the materials was very low, $0.2-2.4 \%$. It was demonstrated that supporting of LSF perovskite on zirconia and silica at $25 \mathrm{wt} \%$ loading increases the CO yield normalized per gram of LSF by a factor of $\sim 2$ [24]. However, this decreases the $\mathrm{CO}$ yield normalized per gram catalyst by the same extent to about $400 \mu \mathrm{mol} \mathrm{CO} \mathrm{g}{ }^{-1}$.

Marin et al. [12] prepared and characterized pure samples of $\mathrm{Fe}_{2} \mathrm{O}_{3}$ (hematite) and $\mathrm{CeO}_{2}$ (ceria) and their mixtures $\left(20 \%, 50 \%, 70 \%\right.$, and $\left.90 \% \mathrm{CeO}_{2}\right)$. The $\mathrm{CO}$ rate and capacity were measured at $600{ }^{\circ} \mathrm{C}$ by first reducing the samples with $5 \% \mathrm{H}_{2} / \mathrm{He}$ and then oxidation with $5 \% \mathrm{CO}_{2}$. The $\mathrm{CO}$ capacity of the pure compounds was low $\left(150 \mu \mathrm{mol} \mathrm{CO} \mathrm{g}-1 \mathrm{Fe}_{2} \mathrm{O}_{3}\right.$ at $\left.600{ }^{\circ} \mathrm{C}\right)$ and reached a maximum at $20 \%$ ceria, although deactivation was measured after 10 cycles [12]. Three types of deactivation were identified: sintering, Fe segregation from solid solution, and perovskite formation. Perovskite $\left(\mathrm{CeFeO}_{3}\right)$ formed in the first tens of cycles lead to a loss of oxygen storage capacity, as it is nonreducible. Marin et al. [25] synthesized a novel $\mathrm{Fe}_{2} \mathrm{O}_{3} / \mathrm{ZrO}_{2} @ \mathrm{ZrO}_{2}$ OSM material by coating $\mathrm{Fe}_{2} \mathrm{O}_{3} / \mathrm{ZrO}_{2}$ core material with a $\mathrm{ZrO}_{2}$ nanoshell, which displayed high stability in a 100 cycles run at $650{ }^{\circ} \mathrm{C}$. The redox behavior of modified 
iron oxide $\left(80 \mathrm{wt} \% \mathrm{Fe}_{2} \mathrm{O}_{3}-\mathrm{Ce}_{0.5} \mathrm{Zr}_{0.5} \mathrm{O}_{2}\right.$ ) was investigated for 500 redox cycles at $750-850{ }^{\circ} \mathrm{C}$ [26]. The measured kinetic data indicated that reaction rates of reduction with $\mathrm{H}_{2}$ were always faster than for oxidation with $\mathrm{CO}_{2}$ at the same conditions.

Hexaaluminates are widely used in catalysis for high-temperature applications like catalytic combustion [31-34], partial oxidation [35,36] or $\mathrm{CO}_{2}$ reforming [37-39]. They have general formula $\mathrm{AB}_{y} \mathrm{Al}_{12-y} \mathrm{O}_{19-\delta}$ where $\mathrm{A}$ represents cation with charge from $1+$ to $3+$ such as $\mathrm{Na}, \mathrm{Ba}, \mathrm{La}$, or $\mathrm{Sr}$. They are located in the mirror plane between the spinel blocks of close packed oxide ions in the lattice. The component $\mathrm{B}\left(\mathrm{Fe}, \mathrm{Co}, \mathrm{Mn}\right.$, or Ni) substitutes $\mathrm{Al}^{3+}$ ions inside the spinel blocks [40]. The type of hexaaluminate structure depends on the valence and ionic radius of substituents: $\mathrm{La}$, $\mathrm{Sr}$ for magnetoplumbite or $\mathrm{Ba}, \mathrm{Na}$ for $\beta$-alumina type [41]. Iron substitutes tetrahedral $\mathrm{Al}^{3+}$ as component $\mathrm{B}$ in spinel blocks [42]. In this case, the high thermal stability of hexaaluminate framework is preserved due to keeping the framework charge neutrality $[43,44]$. Hexaaluminates with increased surface area may be prepared by advanced synthesis strategies like solvent-free synthesis [45] or templating [46,47]. Lately, it was found a reasonable catalytic activity of $\mathrm{Ba}$, Sr hexaaluminates without transition metals in RWGS at $850^{\circ} \mathrm{C}$ [48]. Fe-Al substitution and promotion with potassium renders high catalytic activity to hexaaluminate in $\mathrm{CO}_{2}$ hydrogenation as a first step of RWGS-FTS process at low temperature $[49,50]$. This material demonstrated high activity in RWGS at $320^{\circ} \mathrm{C}$ with no methanation [49-51].

BaFe-hexaaluminate with $60 \%$ degree of $\mathrm{Al}^{3+}$ to $\mathrm{Fe}^{3+}$ exchange in its structure facilitates RWGS according to redox mechanism [50]. $\mathrm{CO}_{2}$ is adsorbed at surface oxygen vacancies associated with $\mathrm{Fe}^{2+}$ ions forming carbonate intermediates. They are further converted to $\mathrm{CO}$ leaving oxygen vacancies filled with oxygen ions associated with iron in form of $\mathrm{Fe}^{3+} . \mathrm{H}_{2}$ reduction of oxidized catalyst regenerates the active sites-oxygen vacancies associated with $\mathrm{Fe}^{2+}$ ions, making the full process completely reversible [50]. Therefore, Fe-substituted Ba-hexaaluminate may catalyze RWGS conducted at CL mode. It may be anticipated the efficient performance of Fe-loaded Ba-hexaaluminate especially in its completely Fe-substituted form of hexaferrite $\mathrm{BaFe}_{12} \mathrm{O}_{19}$ due to high concentration of oxygen ions on its crystallographic facets. Our estimations based on Rietveld refinement of XRD data gave $5.9 \mathrm{O} / \mathrm{nm}^{2}$ for (1-10), $7.7 \mathrm{O} / \mathrm{nm}^{2}$ for (110), and 13.2 O/nm² for (001) planes. The Fe/O ratio in Fe-containing mixed oxides affects the amount of surface oxygen ions that may be eliminated at the reaction conditions by partial reduction of adjacent $\mathrm{Fe}^{3+}$ ions. Hexaaluminates display high $\mathrm{Fe} / \mathrm{O}$ ratio (i.e., 0.63 in magneto-plumbite $\mathrm{BaFe}_{12} \mathrm{O}_{19}$ ) similar to $\mathrm{Fe}_{2} \mathrm{O}_{3}$ and twice more than perovskites $\mathrm{AFeO}_{3}$ (0.33). In the present work, for the first time it was investigated the $\mathrm{CL} \mathrm{CO}$ splitting performance of Fe-substituted Ba-hexaaluminates with $60 \%$ and $100 \%$ degree of $\mathrm{Al}^{3+}$ to $\mathrm{Fe}^{3+}$ exchange in its structure obtained by direct synthesis. The effects of surface area, promotion with potassium, and phases stability and transformations on the efficiency of Fe-substituted Ba-hexaaluminates were studied.

\section{Results and Discussion}

\subsection{Structure, Texture, and $\mathrm{H}_{2}$-Reduction Behavior of Fe-Substituted Ba-Hexaaluminates}

According to X-Ray diffraction (XRD) patterns (Figure 1), both as-synthesized Fe-substituted Ba-hexaaluminates with degree of $\mathrm{Al}^{3+}$ to $\mathrm{Fe}^{3+}$ exchange in hexagonal structure of $60 \%$ and $100 \%$ consisted of alternatively stacked spinel blocks of closed packed oxide ions and mirror planes [41]. The XRD patterns shown in Figure 1a correspond to the reported structure of Fe-substituted Ba-hexaaluminates [50,52-54]. Our BaFeHAl material has a $\beta$-alumina type framework [50] of hexagonal symmetry (ICDD card 84-1786) with lattice parameters $\mathrm{a}=5.785 \AA$; $\mathrm{c}=22.852 \AA$ similar to the structure of $\mathrm{BaFe}_{12} \mathrm{O}_{19}$ [55]. The crystollagraphic positions of XRD reflections recorded with our BaFeHF material corresponded to the same structure were shifted to lower angles. This is a result of asymmetric widening of the hexagonal unit cell $(a=b=5.902 \AA ; c=23.235 \AA)$ caused by the increased extent of $\mathrm{Al}^{3+}$ to $\mathrm{Fe}^{3+}$ substitution. The XRD patterns of BaFeHF material shown in Figure 1a are in agreement with magnetoplumbite structure displaying the unit cell parameters $\mathbf{a}$ and $\mathbf{c}$ similar to that reported in the literature [53], ICDD card 79-1742. The iron and aluminum atoms occupy the same positions in the 
unit cells of $\mathrm{BaFeHAl}$ and BaFeHF materials (Figure 1b,c) with different bonds length determined by ionic radii of corresponding ions. According to Rietveld refinement, part of iron ions' positions in the unit cell of hexaaluminate structure $\mathrm{BaFe}_{12} \mathrm{O}_{19}[50,53,54]$ in our co-precipitated materials remain not occupied living cationic vacancies. Therefore, the formula of these materials followed from XRD data differs from this classical composition containing $11(\mathrm{Al}+\mathrm{Fe}$ ) atoms for $\mathrm{BaFeHAl}$ and $11 \mathrm{Fe}$ atoms for BaFeHF with less oxygens for keeping the crystals' electroneutrality.
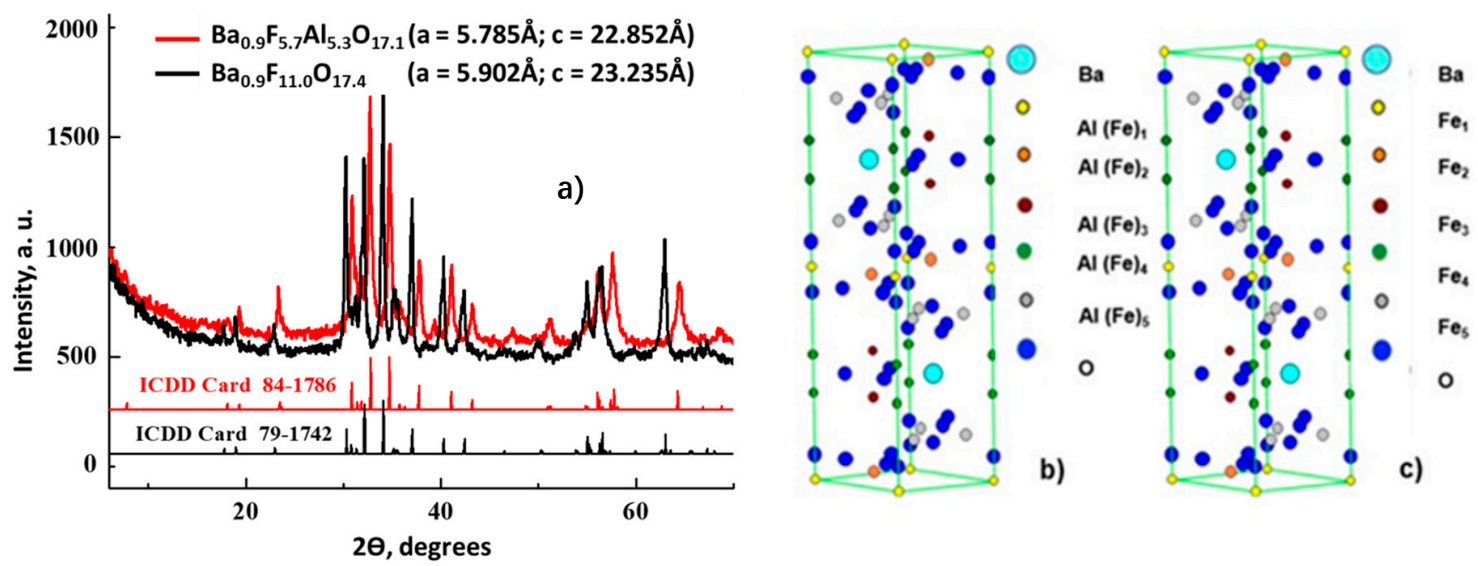

Figure 1. (a) XRD patterns of as as-prepared Fe-substituted Ba-Hexaaluminates: BaFeHAl, BaFeHF; Atomic distributions in unit cells structures of BaFeHAl (b) and BaFeHF (c). The crystallographic positions $1-5$ of $\mathrm{Al}(\mathrm{Fe})$ atoms in the structure have different oxygen environments.

Table 1 depicts the chemical compositions and texture parameters of $\mathrm{BaFeHAl}$ and $\mathrm{BaFeHF}$ tested in RWGS by chemical looping. The texture of co-precipitated (CP) and carbon-templated (CT) materials.

Table 1. Composition and texture parameters of $\mathrm{BaFeHAl}$ and $\mathrm{BaFeHF}$ materials tested in $\mathrm{CO}_{2}$ splitting by chemical looping.

\begin{tabular}{|c|c|c|c|c|c|}
\hline Catalysts & Preparation Method & Chemical Formula & $\begin{array}{c}\text { Surface Area, } \\
\mathrm{m}^{2} \mathrm{~g}^{-1}\end{array}$ & $\begin{array}{c}\text { Pore Volume, } \\
\mathrm{cm}^{3} \mathrm{~g}^{-1}\end{array}$ & $\begin{array}{l}\text { Average Pore } \\
\text { Diameter, nm }\end{array}$ \\
\hline BaFeHAl & $\mathrm{CP}$ & $\mathrm{Ba}_{0.9} \mathrm{Al}_{5.7} \mathrm{Fe}_{5.3} \mathrm{O}_{17.1}$ & 5 & 0.02 & 14 \\
\hline BaFeHAl-20 & $\mathrm{CT}$ & $\mathrm{Ba}_{0.8} \mathrm{Al}_{5.1} \mathrm{Fe}_{5.3} \mathrm{O}_{17.8}$ & 20 & 0.09 & 17 \\
\hline BaFeHAl-30 & CP-HEM & $\mathrm{Ba}_{0.9} \mathrm{Al}_{5.7} \mathrm{Fe}_{5.3} \mathrm{O}_{17.1}$ & 30 & 0.14 & 19 \\
\hline $6 \% \mathrm{~K} / \mathrm{BaFeHAl}$ & $\mathrm{CP}$ & $6 \% \mathrm{~K} / \mathrm{Ba}_{0.9} \mathrm{Al}_{5.7} \mathrm{Fe}_{5.3} \mathrm{O}_{17.1}$ & 4 & 0.02 & 20 \\
\hline $6 \% \mathrm{~K} / \mathrm{BaFeHAl}-20$ & $\mathrm{CT}$ & $6 \% \mathrm{~K} / \mathrm{Ba}_{0.8} \mathrm{Al}_{5.1} \mathrm{Fe}_{5.3} \mathrm{O}_{17.8}$ & 13 & 0.05 & 17 \\
\hline $6 \% \mathrm{~K} / \mathrm{BaFeHAl}-30$ & CP-HEM & $6 \% \mathrm{~K} / \mathrm{Ba}_{0.9} \mathrm{Al}_{5.7} \mathrm{Fe}_{5.3} \mathrm{O}_{17.1}$ & 20 & 0.12 & 36 \\
\hline $\mathrm{BaFeHF}$ & $\mathrm{CP}$ & $\mathrm{Ba}_{0.9} \mathrm{Fe}_{11.0} \mathrm{O}_{17.4}$ & 2 & 0.01 & 18 \\
\hline BaFeHF-18 & CP-HEM & $\mathrm{Ba}_{0.9} \mathrm{Fe}_{11.0} \mathrm{O}_{17.4}$ & 18 & 0.07 & 16 \\
\hline $6 \% \mathrm{~K} / \mathrm{BaFeHF}$ & $\mathrm{CP}$ & $6 \% \mathrm{~K} / \mathrm{Ba}_{0.9} \mathrm{Fe}_{11.0} \mathrm{O}_{17.4}$ & 2 & 0.01 & 20 \\
\hline $6 \% \mathrm{~K} / \mathrm{BaFeHF}-18$ & CP-HEM & $6 \% \mathrm{~K} / \mathrm{Ba}_{0.9} \mathrm{Fe}_{11.0} \mathrm{O}_{17.4}$ & 8 & 0.03 & 16 \\
\hline
\end{tabular}

With $60 \%$ and $100 \%$ degree of $\mathrm{Al}^{3+}$ to $\mathrm{Fe}^{3+}$ exchange, it was also characterized after modification with potassium ( $6 \% \mathrm{wt}$ ) and after High Energy Ball Milling (HEM). Carbon-templating and HEM increased the surface area of BaFeHAl material from $5 \mathrm{~m}^{2} \mathrm{~g}^{-1}$ to 20 and $30 \mathrm{~m}^{2} \mathrm{~g}^{-1}$, respectively, without change of phase and chemical composition. In the case of BaFeHF application of HEM, the surface area increased from $2 \mathrm{~m}^{2} \mathrm{~g}^{-1}$ to $18 \mathrm{~m}^{2} \mathrm{~g}^{-1}$ with no change in structure and composition. Carbon templating decreases the platelets size of primary nanocrystals of $\mathrm{BaFeHAl}$ from 0.3-0.7 (co-precipitation) to $0.1-0.4 \mu \mathrm{m}$ forming additional mesopores between nanocrystals aggregates [50]. This is reflected by the appearance of small mesopores with radius of $<70 \AA$ (Figure $2 b$ ). The HEM treatment further decreased the size of co- precipitated BaFeHAl primary crystals due to grinding to $0.03-0.1 \mu \mathrm{m}$ (Figure $3 \mathrm{c}, \mathrm{d}$ ), strongly increasing the pore volume at wide range of pore radii (Figure 2). 

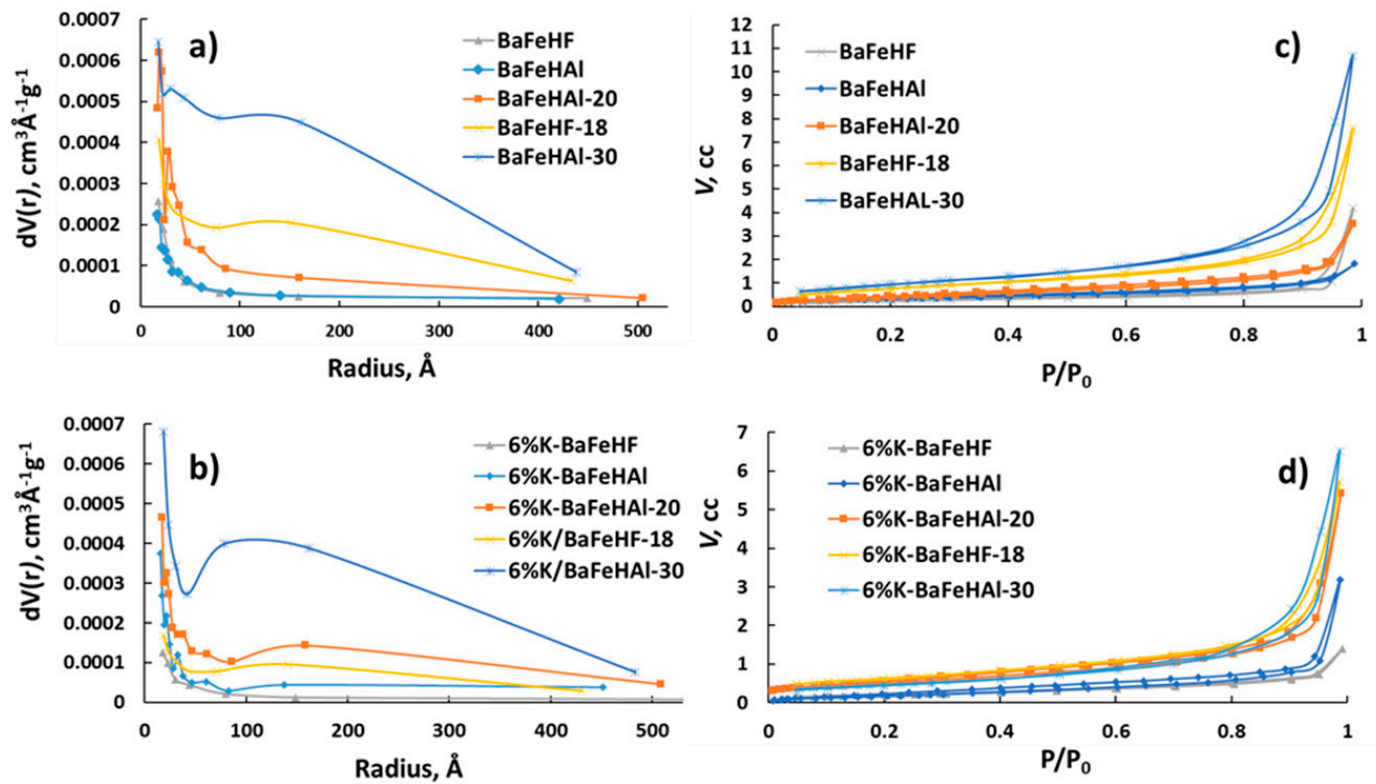

Figure 2. Pore size distributions $(\mathbf{a}, \mathbf{b})$ and $\mathrm{N}_{2}$ adsorption-desorption isotherms (c,d) of BaFeHAl, BaFeHF, BaFeHAl-20, BaFeHAl-30, and BaFeHF-18 catalysts-as-prepared and doped with $6 \mathrm{wt} \%$ potassium.
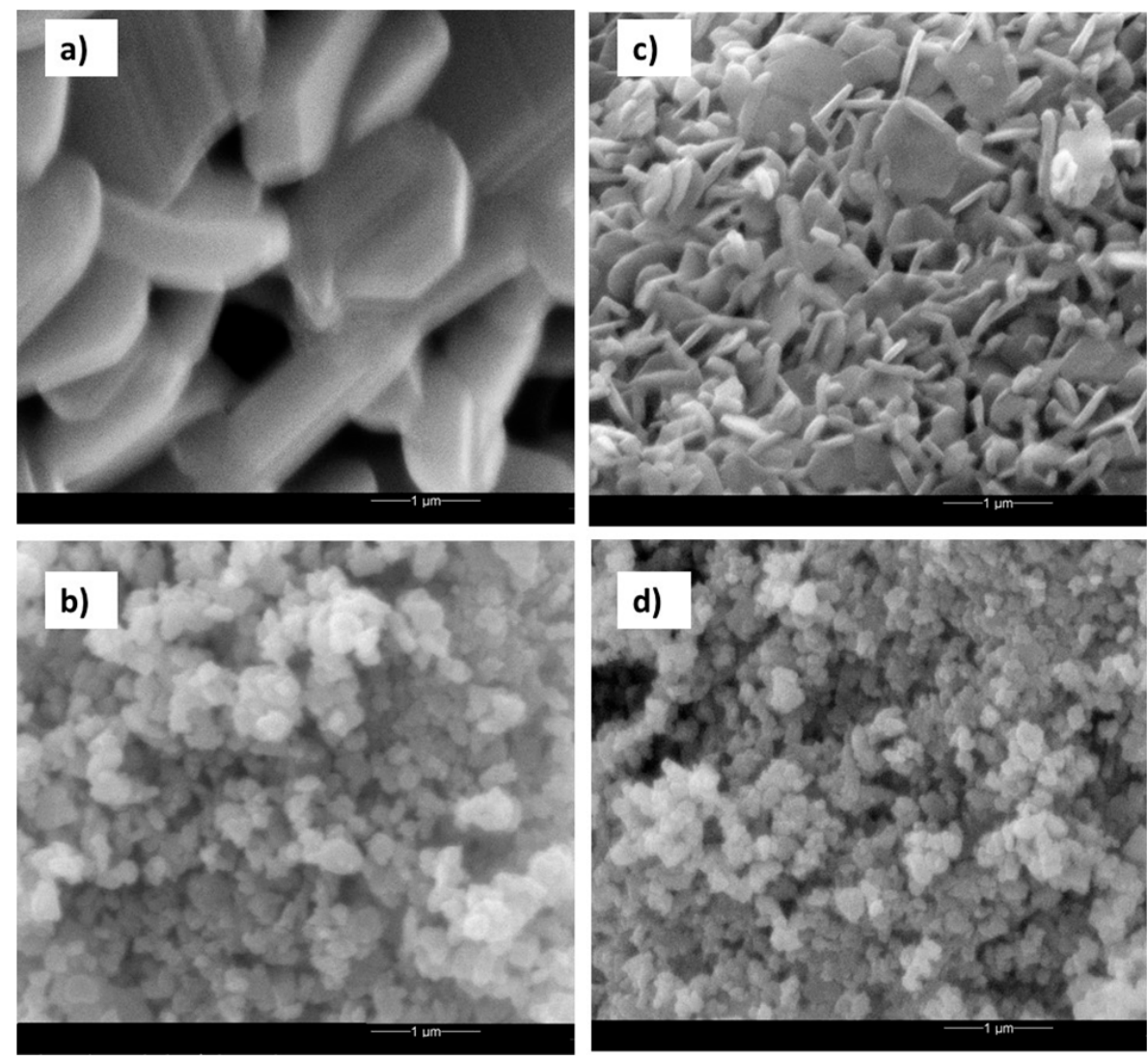

Figure 3. SEM micrographs of BaFeHF and BaFeHAl before $(\mathbf{a}, \mathbf{c})$ and after HEM treatment $(\mathbf{b}, \mathbf{d})$, respectively.

Similar effect was observed after HEM treatment of BaFeHF (Figures 2 and 3a,b). HEM treatment decreased the average crystal size of both co-precipitated BaFeHAl and BaFeHF materials to the level detectable from the widening of XRD reflections, 30 and $40 \mathrm{~nm}$, respectively. Promotion with potassium decreased the surface area of all materials due to aggregation of primary crystals to less porous 
agglomerates [50]. This brings the increase of pore diameter due to the predominant disappearance of small pores (Figure 2a,c).

\subsection{Factors Affecting the Performance of Fe-Substituted Ba-Hexaaluminates}

RWGS includes two consecutive steps: $\mathrm{H}_{2}$-reduction and $\mathrm{CO}_{2}$ oxidation of catalyst at elevated temperatures, where thermal stability of the structure of selected phases is critical for testing their performance. The $\mathrm{BaFeHAl}$ and $\mathrm{BaFeHF}$ materials are very stable at oxidative conditions being prepared by annealing at temperatures of $>1000^{\circ} \mathrm{C}$. However, they may decompose into different phases in reductive $\mathrm{H}_{2}$-atmosphere [49]. The spectra of water evolution during Temperature Programmed Reduction (TPR) of as-prepared BaFe-hexaxaluminate and BaFe-hexaferrite are shown in Figure 4. After low-temperature peaks corresponding to removal of adsorbed water, the spectra contain groups of high-temperature peaks corresponding to water evolution due to $\mathrm{H}_{2}$-reduction of corresponding bulk phases. BaFeHAl is more stable to reduction compared with BaFeHF: high-temperature water evolution starts at 450 and $300^{\circ} \mathrm{C}$, respectively. In addition, the intensity of low-temperature reduction peak centered at $\sim 400^{\circ} \mathrm{C}$ in case of $\mathrm{BaFeHF}$ is significantly higher compared with that for $\mathrm{BaFeHAl}$ centered at $550^{\circ} \mathrm{C}$. This may be a result of deep deoxygenation of the structure of both materials in hydrogen atmosphere at temperatures $>300-350^{\circ} \mathrm{C}$ for BaFeHF and $>450-550{ }^{\circ} \mathrm{C}$ for BaFeHAl, and their conversion to other oxygen-depleted phases. The phase compositions of as-prepared BaFeHAl and BaFeHF catalysts after treatment in $10 \% \mathrm{H}_{2}$-Ar flow in a tubular reactor at $35 \mathrm{~cm}^{3} \mathrm{~min}^{-1} \mathrm{gram}^{-1}$ for 20 min are shown in Table 2. From these data it follows that at $\mathrm{H}_{2}$-reduction step of RWGS-CL cycle the $\mathrm{BaFeHAl}$ phase is stable up to $450{ }^{\circ} \mathrm{C}$ and the $\mathrm{BaFeHF}$ phase up to $350{ }^{\circ} \mathrm{C}$.

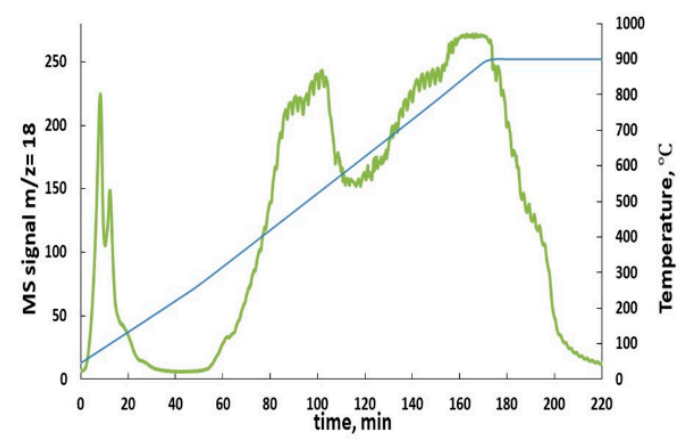

(a)

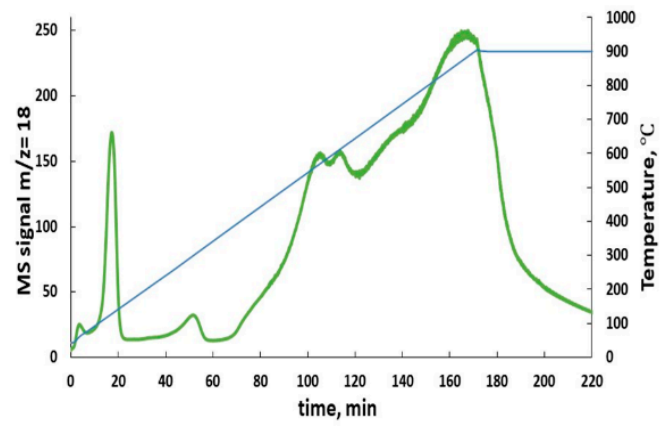

(b)

Figure 4. Temperature Programmed Reduction (TPR) water evolution spectra of as-prepared BaFeHF (a) and $\mathrm{BaFeHAl}(\mathbf{b})$.

The results of RWGS-CL presented in Figure 5 show that the CO capacity of this material increases proportionally to its surface area both in as-prepared and K-promoted forms. K-promoted BaFeHAl displayed significantly higher $\mathrm{CO}$ capacity compared with as-prepared material in spite of lower surface area. Specific CO capacity (SC) of K-promoted catalysts normalized to the unit of surface area $\left(\mu \mathrm{mol} \mathrm{m}{ }^{-2}\right)$ increased by a factor of 1.8-3.2. This effect is related to higher concentration of oxygen vacancies in reduced Fe-materials due to reductive action of potassium [50,56]. The efficiency of $\mathrm{BaFeHAl}$ and $\mathrm{BaFeHF}$ catalysts with similar surface areas was compared in isothermal RWGS-CL runs at $350^{\circ} \mathrm{C}$. Data presented in Figure 6 show that BaFeHF display higher $\mathrm{CO}$ capacity, and thus is more efficient than BaFeHAl. The SC is 3.5 and $2.6 \mu \mathrm{mol} \mathrm{m}^{-2}$ for BaFeHF and BaFeHAl, respectively. The ratio $\mathrm{SC}_{\mathrm{BaFeHF}} / \mathrm{SC}_{\mathrm{BaFeHAl}}$ is close to the ratio of iron content in these materials (Table 1), reflecting that the active sites for RWGS reaction are anionic vacancies formed at the catalysts surface at $\mathrm{H}_{2}$-reduction step due to the conversion of $\mathrm{Fe}^{3+}$ to $\mathrm{Fe}^{2+}[50,56]$. Their surface concentration should be proportional to the iron content taking in account the similar structure of both materials. Promoting BaFeHF with K increased its CO capacity (Figure 6) and SC value to $8.7 \mu \mathrm{mol} \mathrm{m}^{-2}$. 
Table 2. Phase composition of $6 \% \mathrm{~K} / \mathrm{BaFeHAl}-30$ and $6 \% \mathrm{~K} / \mathrm{BaFeHF}-18$ after $\mathrm{H}_{2}$-reduction.

\begin{tabular}{lcccccc}
\hline \multicolumn{1}{c}{ Catalyst } & Phase Composition, $\mathbf{w t} \mathbf{\%}$ of As-Prepared Catalysts after $\mathbf{H}_{\mathbf{2}}$-Treatment at Temperature, ${ }^{\circ} \mathbf{C}$ \\
\hline $\mathbf{6} \% \mathbf{K} / \mathbf{B a F e H A l}-\mathbf{3 0}$ & $\mathbf{3 5 0}$ & $\mathbf{4 0 0}$ & $\mathbf{4 5 0}$ & $\mathbf{5 0 0}$ & $\mathbf{5 5 0}$ & $\mathbf{6 0 0}$ \\
\hline $\mathrm{BaFeHAl}$ & 100 & 100 & 100 & 38 & 0 & 0 \\
\hline $\mathrm{BaFeHF}$ & - & - & - & 46 & 73 & 71 \\
\hline $\mathrm{BaCO}_{\mathbf{r}}$ & - & - & - & 8 & 9 & 12 \\
\hline $\mathrm{Fe}_{3} \mathrm{O}_{4}$ & - & - & - & - & 7 & 6 \\
\hline $\mathrm{Al}_{2} \mathrm{O}_{3}$ & - & - & - & 8 & 11 & 11 \\
\hline $\mathbf{6} \% \mathbf{K} / \mathbf{B a F e H F - 1 8}$ & $\mathbf{3 5 0}$ & $\mathbf{4 0 0}$ & $\mathbf{5 0 0}$ & $\mathbf{5 0 0}$ & $\mathbf{5 5 0}$ & $\mathbf{6 0 0}$ \\
\hline $\mathrm{BaFeHF}$ & 100 & 88 & 50 & 26 & 0 & 0 \\
\hline $\mathrm{Fe} \mathrm{O}_{4}$ & - & 9 & 41 & 55 & 80 & 41 \\
\hline $\mathrm{FeO}$ & - & 3 & 5 & 13 & 11 & 49 \\
\hline $\mathrm{BaCO}$ & - & - & 4 & 6 & 9 & 6 \\
\hline $\mathrm{BaO}$ & - & - & - & - & - & 4 \\
\hline
\end{tabular}

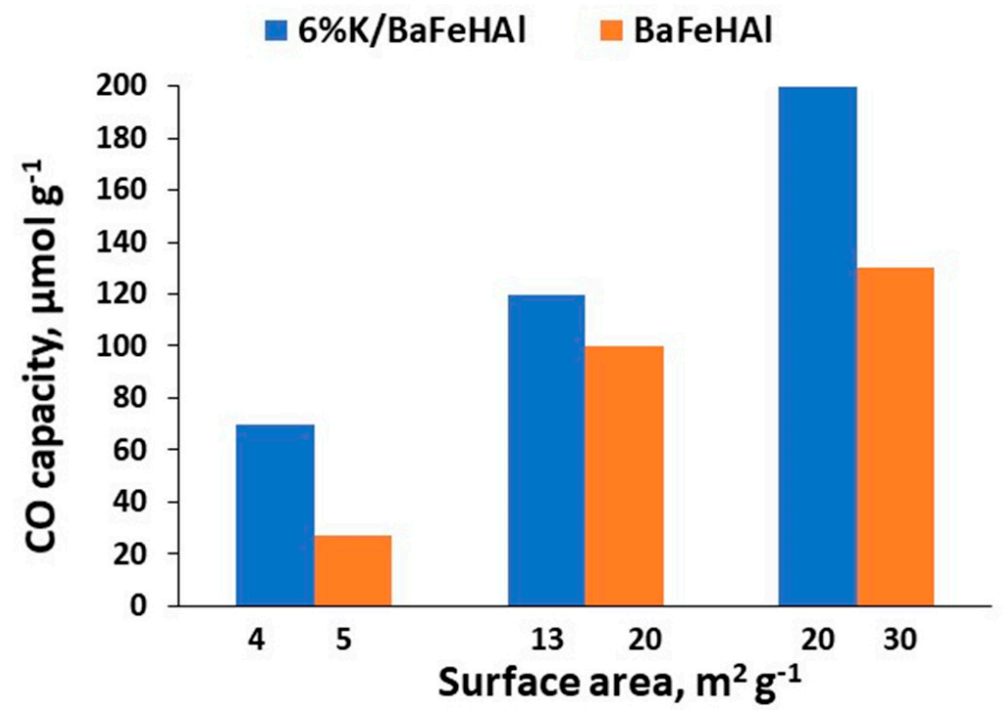

Figure 5. Effect of K-promotion and surface area of BaFeHAl catalyst on the CO capacity at $450{ }^{\circ} \mathrm{C}$.

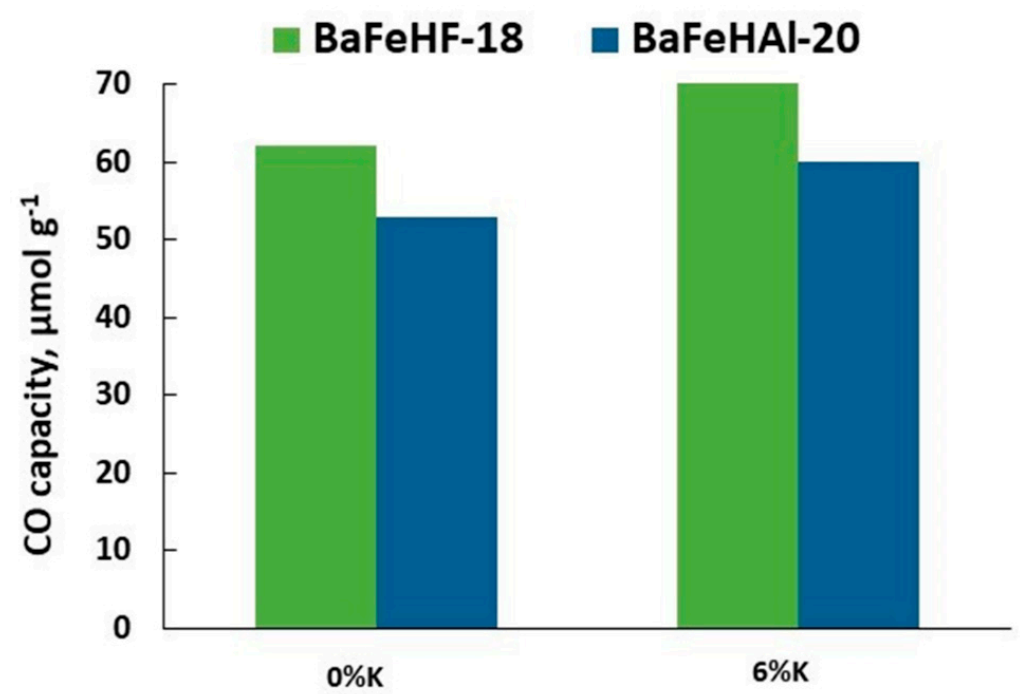

Figure 6. Comparison of the CO capacity in RWGS-CL of as-prepared and K-promoted BaFeHAl and BaFeHF at $350{ }^{\circ} \mathrm{C}$. 
Increasing of $\mathrm{H}_{2}$-reduction temperature $\left(\mathrm{T}_{\mathrm{r}}\right)$ of $\mathrm{BaFeHF}$ catalyst beyond $350{ }^{\circ} \mathrm{C}$ leads to decomposition of this phase converting it to iron oxides, barium oxide, and carbonate (Table 2). Ba-compounds are not active in the redox cycle. Presented in Figure 7 are the results of non-isothermal testing of $6 \% \mathrm{KBaFeHF}-18$ keeping the reduction temperature at $350{ }^{\circ} \mathrm{C}$ that avoids catalysts reductive decomposition. Increasing $\mathrm{CO}_{2}$ oxidation temperature increased $\mathrm{CO}$ capacity from 68 (Figure 6) to $114\left(\mu \mathrm{mol} \mathrm{g}^{-1}\right)$ (Figure 7a), depicted by the shape of CO production peaks (Figure 7b). XRD analysis indicates that the structure of $6 \% \mathrm{~K} / \mathrm{BaFeHF}$ did not change after the $\mathrm{CO}_{2}$ oxidation step at $550-650{ }^{\circ} \mathrm{C}$. It means that increasing oxidation temperature involves additional $\mathrm{Fe}^{2+}$ ions with lower oxidation ability to the $\mathrm{CO}_{2}$ oxidation process.
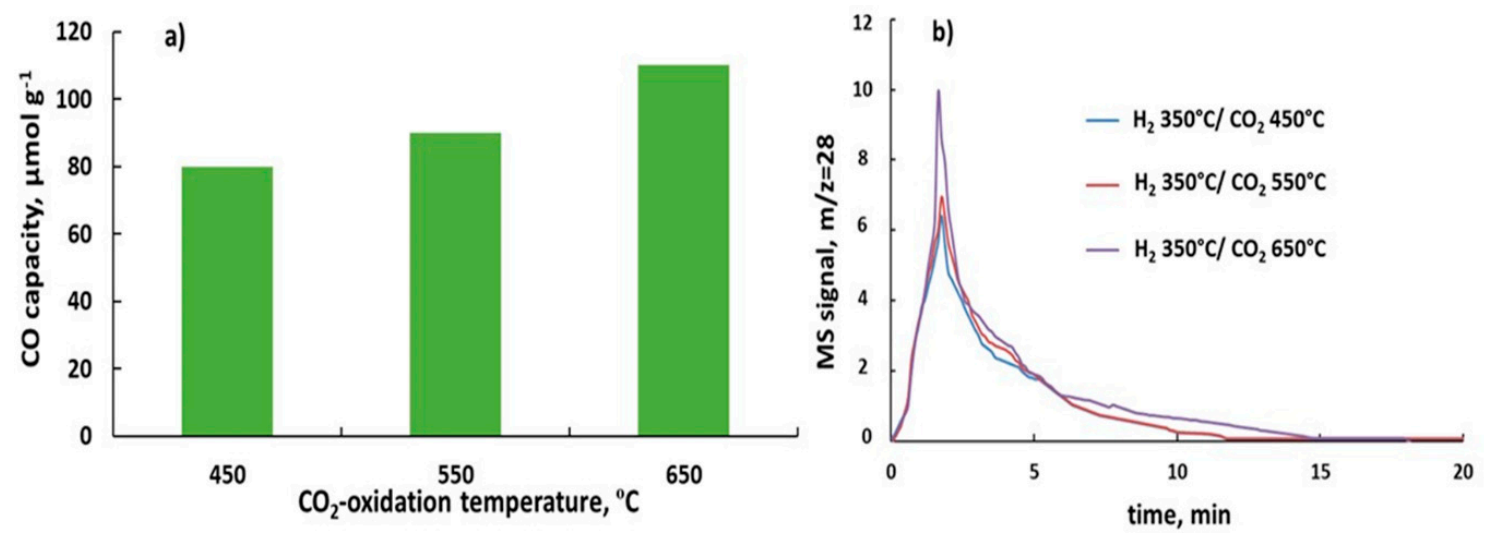

Figure 7. Effect of $\mathrm{CO}_{2}$ oxidation temperature in RWGS-CL cycles at constant $\mathrm{H}_{2}$-reduction at $350{ }^{\circ} \mathrm{C}$ on the CO capacity of $6 \% \mathrm{~K} / \mathrm{BaFeHF}-18$ (a) and CO evolution spectra (b).

The decomposition of BaFeHAl catalyst during $\mathrm{H}_{2}$-reduction step of the RWGS-CL cycle at temperatures of $>450{ }^{\circ} \mathrm{C}$ yields novel thermostable $\mathrm{BaFeHF}_{\mathrm{r}}$ phase as a main component with the depletion of $\mathrm{BaCO}_{3}, \mathrm{Al}_{2} \mathrm{O}_{3}$, and $\mathrm{Fe}_{3} \mathrm{O}_{4}$ phases (Table 2). Since $\mathrm{BaFeHF}$ is a more efficient catalyst, the effect of reduction temperature on $\mathrm{CO}$ capacity of $6 \% \mathrm{~K} / \mathrm{BaFeHAl}$ was studied at the temperature range of $350-600{ }^{\circ} \mathrm{C}$ where the catalyst contained $\mathrm{BaFeHAl}$ or $\mathrm{BaFeHF}_{\mathrm{r}}$ phases, keeping constant the $\mathrm{CO}_{2}$ oxidation temperature at $450{ }^{\circ} \mathrm{C}$. The results of this non-isothermal testing series are shown in Figure 8.
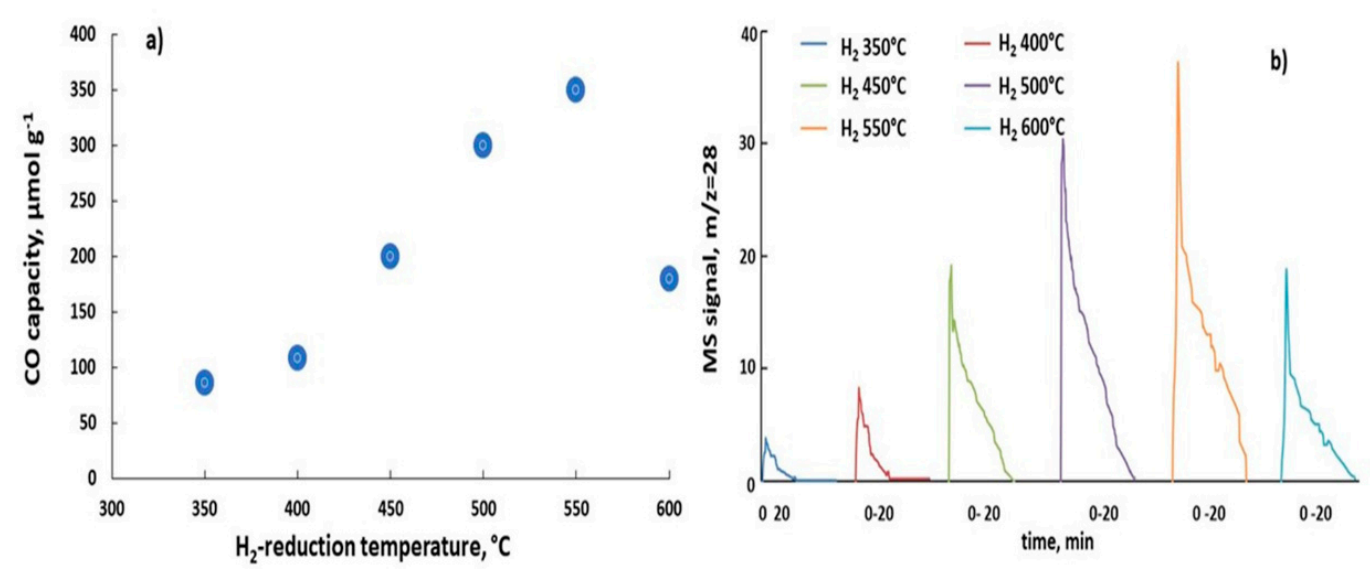

Figure 8. Effect of reduction temperature on $\mathrm{CO}$ capacity of $6 \% \mathrm{~K} / \mathrm{BaFeHAl}-30$. The $\mathrm{CO}_{2}$ oxidation step conducted at $450{ }^{\circ} \mathrm{C}(\mathbf{a})$ and $\mathrm{CO}$ evolution spectra (b).

The $\mathrm{CO}$ capacity of $\mathrm{K}$-promoted $\mathrm{BaFeHAl}$ reached a maximum at $550{ }^{\circ} \mathrm{C}$, increasing by a factor of 1.75 compared to the value at $450^{\circ} \mathrm{C}$ (Figure 8a). This is illustrated by changes of the shape of $\mathrm{CO}$ production peaks recorded at $450{ }^{\circ} \mathrm{C}$ in $\mathrm{CO}_{2}$ oxidation step (Figure 8b). No changes of catalysts phase composition were detected by $\mathrm{XRD}$ after $\mathrm{CO}_{2}$ oxidation step. 
The results are evident for two effects: one is the improved thermal stability of $\mathrm{BaFeHF}_{\mathrm{r}}$ obtained from $\mathrm{BaFeHAl}$ compared with direct co-precipitation, and the other is activation of $6 \% \mathrm{~K} / \mathrm{BaFeHAl}$. The latter is related to the formation of $\mathrm{BaFeHF}_{\mathrm{r}}$ phase with a higher activity. $\mathrm{BaCO}_{3}$ and $\mathrm{Al}_{2} \mathrm{O}_{3}$ cannot participate in redox cycles, and $\mathrm{Fe}_{3} \mathrm{O}_{4}$ formed together with $\mathrm{BaFeHF}_{\mathrm{r}}$ (Table 2) has low activity in RWGS-CL [12] and its content is small. The $6 \% \mathrm{~K} / \mathrm{BaFeHAl}$ was characterized by $\mathrm{XRD}, \mathrm{N}_{2}$-adsorption, and XPS after reduction at different temperatures. Figure 9 compares the XRD patterns of $6 \% \mathrm{~K} / \mathrm{BaFeHF}$ obtained by co-precipitation with the XRD patterns of BaFeHF component of $6 \% \mathrm{~K} / \mathrm{BaFeHAl}$ reduced at $550{ }^{\circ} \mathrm{C}$. The latter was derived from the experimental XRD data by deconvolution using Rietveld program that separates reflections related to $\mathrm{BaFeHF}$ phase from that characteristic of $\mathrm{BaCO}_{3}$ and $\mathrm{Al}_{2} \mathrm{O}_{3}$. The $\mathrm{XRD}$ patterns of $\mathrm{BaFeHF}_{\mathrm{r}}$ after reduction of $6 \% \mathrm{~K} / \mathrm{BaFeHAl}$ at 500,550 , and $600{ }^{\circ} \mathrm{C}$ (Table 2) were identical.

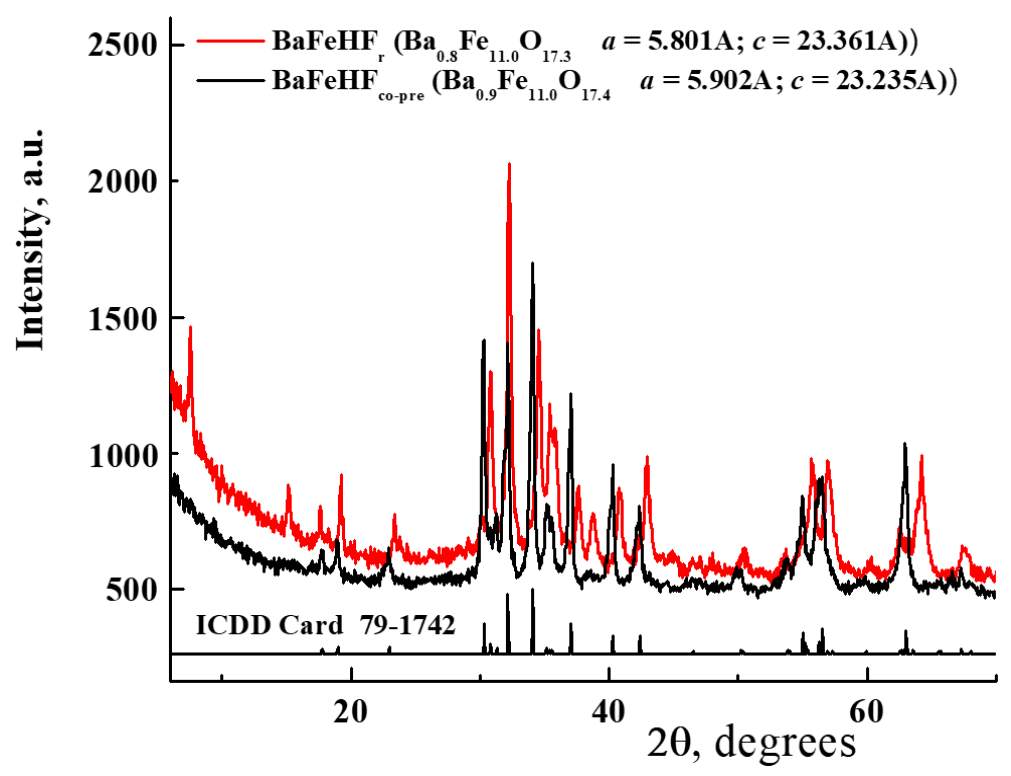

Figure 9. XRD patterns of BaFeHF phases obtained by co-precipitation and K-promotion (black line) and by decomposition of $6 \% \mathrm{~K} / \mathrm{BaFeHAl}-30$ material during reduction at $550{ }^{\circ} \mathrm{C}$ (red line).

Comparison of XRD patterns of BaFeHF phases obtained by co-precipitation and reduction of BaFeHAl (Figure 9) shows significant differences although both structures relate to the same space group $\mathrm{P} 63 / \mathrm{mmc}$ (194). $\mathrm{BaFeHF}_{\mathrm{r}}$ displays two reflections at low angles of $2 \theta=7.6$ and $15.2^{\circ}$ corresponding to planes (002) and (004), respectively, not found in BaFeHF. The relative intensities of XRD peaks are significantly different. In the triad of most intensive peaks corresponding to planes (110), (107), and (114), the relation between intensities is $\mathrm{I}_{110} / \mathrm{I}_{107} / \mathrm{I}_{114}=50 / 90 / 100$ for $6 \% \mathrm{~K} / \mathrm{BaFeHF}$ and $40 / 100 / 65$ for $\mathrm{BaFeHF}_{\mathrm{r}}$. In addition, the XRD reflections related to $\mathrm{BaFeHF}_{\mathrm{r}}$ are shifted to higher angles compared with BaFeHF. This yields significant changes of the unit cell parameters from $\mathrm{a}=5.902 \AA, \mathrm{c}=23.235 \AA$ (BaFeHF) to $\mathrm{a}=5.801 \AA, \mathrm{c}=23.361 \AA\left(\mathrm{BaFeHF}_{\mathrm{r}}\right)$.

Analysis of these variances of XRD patterns using Rietveld method showed that the atomic distributions in the unit cells of BaFeHF and $\mathrm{BaFeHF}_{\mathrm{r}}$ are also different (Tables $\mathrm{S} 1$ and S2). Though the nomenclature of atoms and their positions in the structure is similar in both cases, the coordinates of all atoms, besides $\mathrm{Ba}$ and $\mathrm{Fe}_{1}$, are meaningfully dissimilar, as may be clearly seen along the $\mathrm{c}$ axis ( $\mathrm{Z}$ coordinates). This explains the appearance of reflections (002) and (004) for $\mathrm{BaFeHF}_{\mathrm{r}}$. The differences of intensities of XRD patterns between $\mathrm{BaFeHF}_{\mathrm{co}-\text { pre }}$. and $\mathrm{BaFeHF}_{\mathrm{r}}$ is mainly a result of shifting atomic positions in the hexaferrite structure. Presented in Figure 10 are the oxygen environments of Fe atoms in the framework of both materials. The color of tetrahedra and octahedra corresponds to the color of the groups of Fe atoms in the unit cell as denoted in Figure 1b,c. In both structures the Ba atoms are located at the main points of the lattice symmetry $\mathrm{P} 63 / \mathrm{m}\left(\mathbf{Z}_{\mathbf{B a}}=1 / 4\right.$ and $\left.3 / 4\right)$. This means that $\mathrm{Ba}$ 
atoms are the force centers of stability for this type of crystals. In case of BaFeHF $\mathrm{Co}_{\text {core }}$. (Figure 10a) the yellow-orange zone in the unit cell center between Ba atoms is represented by yellow octahedra including two atoms $\mathrm{Fe}_{1}$ and orange tetrahedra including four atoms $\mathrm{Fe}_{2}$. Located at the top and bottom of this zone are zones of gray octahedra including six atoms $\mathrm{Fe}_{5}$ in each gray zone. Bonding between Ba-atoms and Fe-atoms belonging to the gray zones occurs through brown octahedra including $\mathrm{Fe}_{3}$ atoms (two atoms at every side). The two atoms $\mathrm{Fe}_{4}$ denoted by green color are located in Ba-plane $\mathbf{m}$ with small deviation from $\mathrm{Z}$ axis at half occupancy. These atoms do not have bulk oxygen environment. The character of oxygen environment of $\mathrm{Fe}$ atoms in the lattice of $\mathrm{BaFeHF}_{\mathrm{r}}$ is identical to that in $\mathrm{BaFeHF}_{\mathrm{co}-\mathrm{pre}}$. (Figure 10b). However, due to shifting of atomic positions in the compressed lattice, the octahedral-tetrahedral oxygen environment in yellow-orange and gray zones is distorted with their expansion along $\mathrm{c}$ axis. The most important difference is a significant shift of the positions of green $\mathrm{Fe}_{4}$ atoms along $\mathrm{c}$ axis relative to the plane $\mathbf{m}$ of Ba-atoms located perpendicular to the $\mathrm{c}$ axis at distances of $\frac{1}{4}$ and $\frac{3}{4}$ from the origin. This may be clearly seen in Figure 10 according to positions of green spheres representing $\mathrm{Fe}_{4}$ atoms in unit cells. Due to this shift near these $\mathrm{Fe}_{4}$ atoms, the bulk oxygen surrounding appears evident for the formation of additional Ba-O-Fe bridges in the structure of $\mathrm{BaFeHF}_{\mathrm{r}}$, reinforcing the connection between alternatively stacked spinel blocks. This may explain the higher thermostability of $\mathrm{BaFeHF}_{\mathrm{r}}$ phase formed by reductive decomposition of BaFeHAl compared with that obtained by co-precipitation. The original valence state of iron ions substituting $\mathrm{Al}^{3+}$ ions in hexaaluminate structure is $\mathrm{Fe}^{3+}$. Therefore, the concentration of anionic vacancies originated from reduction of these ions at the catalyst surface to $\mathrm{Fe}^{2+}$ is proportional to the ratio of $\mathrm{Fe}^{2+} / \mathrm{Fe}^{3+}$ that may be measured by XPS.

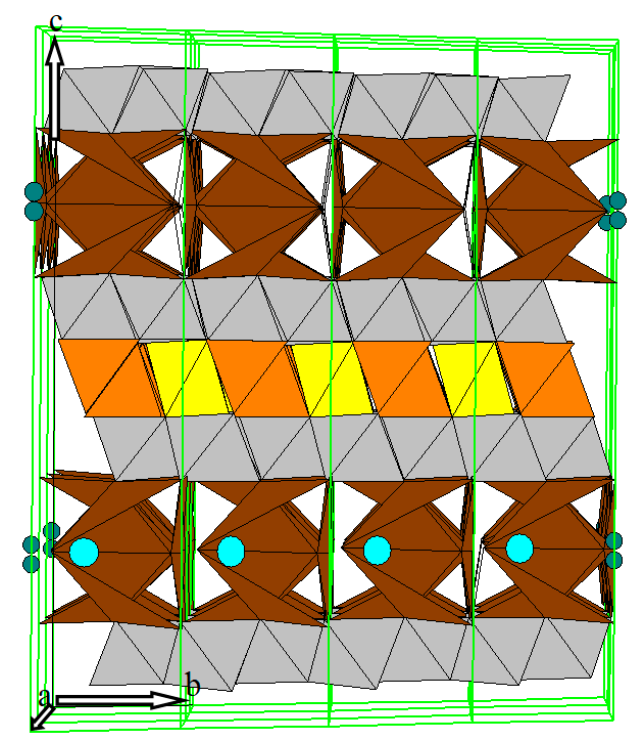

(a)

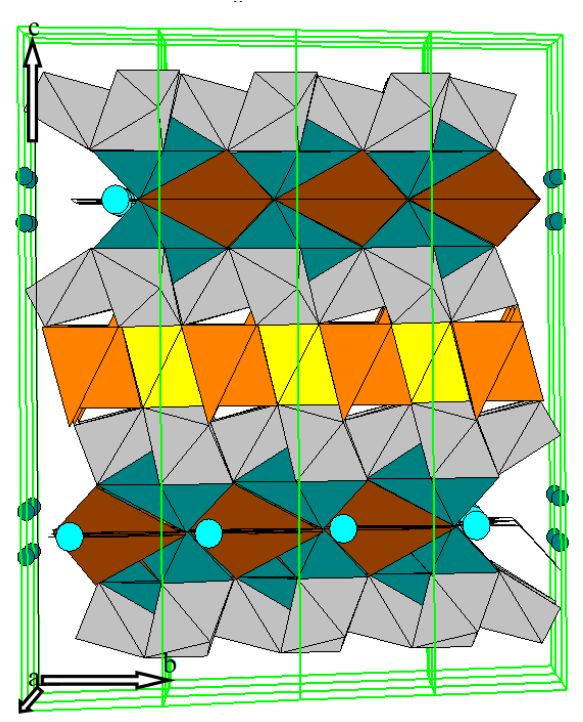

(b)

Figure 10. The oxygen environments of Fe atoms represented as tetrahedra and octahedra in two modifications of BaFeHF phase: (a) $\mathrm{BaFeHF}_{\mathrm{co}-\text { pre; }}$ (b) $\mathrm{BaFeHF}_{\mathrm{r}}$. The colors correspond to groups of atoms as defined in Figure $1 \mathrm{~b}, \mathrm{c} \diamond-\mathrm{Fe}_{1} ; \diamond-\mathrm{Fe}_{2} ; \diamond-\mathrm{Fe}_{3} ; \diamond-\mathrm{Fe}_{4} ; \diamond-\mathrm{Fe}_{5} ; \mathrm{O}-\mathrm{Ba}$.

Shown in Figure 11 are the XPS spectra of the material $6 \% \mathrm{~K} / \mathrm{BaFeHAl}$ reduced at $350-550{ }^{\circ} \mathrm{C}$. The existence of iron ions at different valence state and environment follows from deconvolution of $\mathrm{Fe} 2 \mathrm{p} 3 / 2$, core spectra in three signals. Peaks at lowest energy of 709.3-710.0 eV reflect the existence of $\mathrm{Fe}^{2+}$ ions in the surface layer [50]. The $\mathrm{Fe}^{3+}$ ions at different oxygen environment in the hexaaluminate lattice are represented in XPS spectra by peaks of higher BE of 710.4-711.6 and 712-714 eV [50]. The values of surface $\mathrm{Fe}^{2+} / \mathrm{Fe}^{3+}$ ions ratio were calculated based on their surface concentrations derived from deconvoluted XPS spectra. They are shown in Figure $11 \mathrm{~b}$ as a function of reduction temperature of $6 \% \mathrm{BaFeHAl}$ catalyst. The rate of increase of $\mathrm{Fe}^{2+} / \mathrm{Fe}^{3+}$ ratio in the range $450-600{ }^{\circ} \mathrm{C}\left(9.0 \times 10^{-3}{ }^{\circ} \mathrm{C}^{-1}\right)$ 
is about three times higher than at $350-450{ }^{\circ} \mathrm{C}\left(3.5 \times 10^{-3}{ }^{\circ} \mathrm{C}^{-1}\right)$, corresponding to deeper reduction of iron in $6 \% \mathrm{~K} / \mathrm{BaFeHAl}$. This may be attributed to higher reducibility of $\mathrm{Fe}^{3+}$ ions at the surface of $\mathrm{BaFeHF}$ phase, yielding more $\mathrm{Fe}^{2+}$ ions related with oxygen vacancies that play a role of active sites at the $\mathrm{CO}_{2}$ oxidation step.

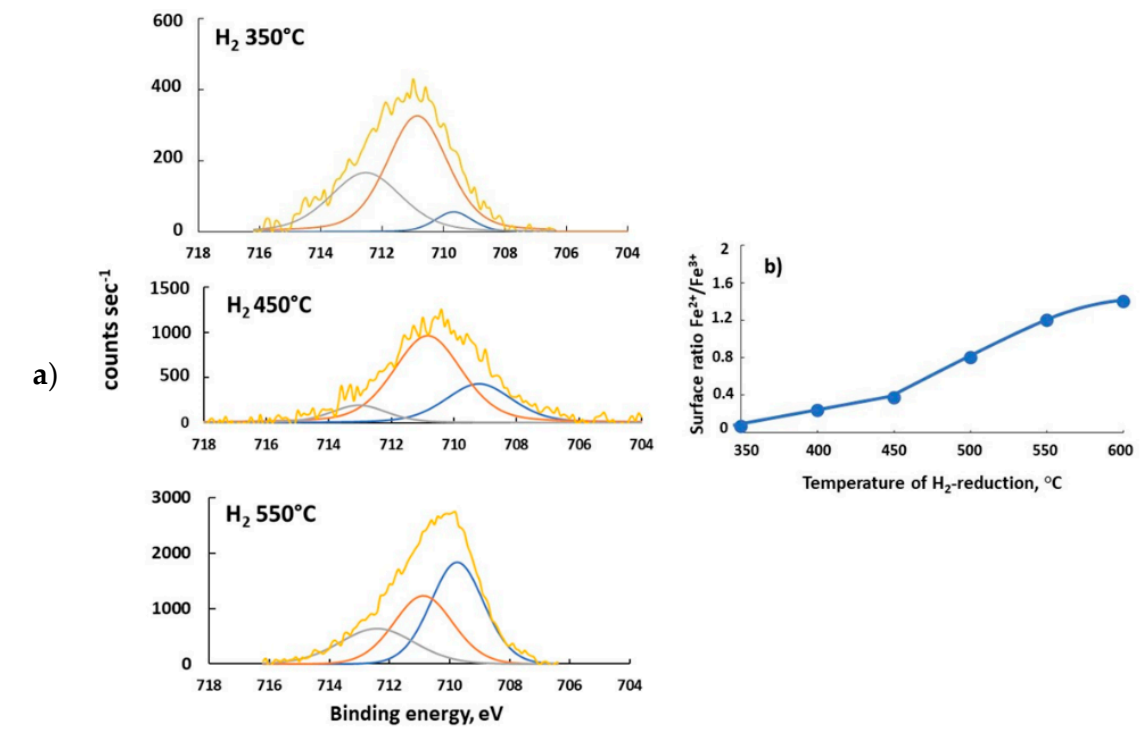

Figure 11. XPS spectra of $6 \% \mathrm{BaFeHAl}-30$ catalyst after reduction at 350,450 , and $550{ }^{\circ} \mathrm{C} \mathrm{Fe}^{2+}, \mathrm{F}^{3+} \mathrm{Oh}$, $\mathrm{Fe}^{3+} \mathrm{Th}(\mathbf{a})$; effect of reduction temperature on the surface $\mathrm{Fe}^{2+} / \mathrm{Fe}^{3+}$ ions ratio calculated based on XPS spectra deconvolution $(\mathbf{b})$.

Since the surface area of reduced $6 \% \mathrm{~K} / \mathrm{BaFeHAl}$ catalyst remains about the same at the range of $350-550{ }^{\circ} \mathrm{C}$ (Figure 12), the $\mathrm{CO}$ capacity of $6 \% \mathrm{~K} / \mathrm{BaFeHAl}$ catalyst strongly increased at $500-550{ }^{\circ} \mathrm{C}$ after complete reductive transformation of $\mathrm{BaFeHAl}$ phase to $\mathrm{BaFeHF}_{\mathrm{r}}$. Further increase of the reduction temperature to $600^{\circ} \mathrm{C}$ did not change the phase composition of the catalyst (Table 2) and crystal size of $\mathrm{BaFeHF}_{\mathrm{r}}, \mathrm{BaCO}_{3}, \mathrm{Al}_{2} \mathrm{O}_{3}$, and $\mathrm{Fe}_{3} \mathrm{O}_{4}$ phases. However, the distortion of nanocrystals aggregates at this temperature reduced the pore volume and decreased the surface area by a factor of $\sim 2$ (Figure 12) that caused catalyst deactivation (Figure 8).

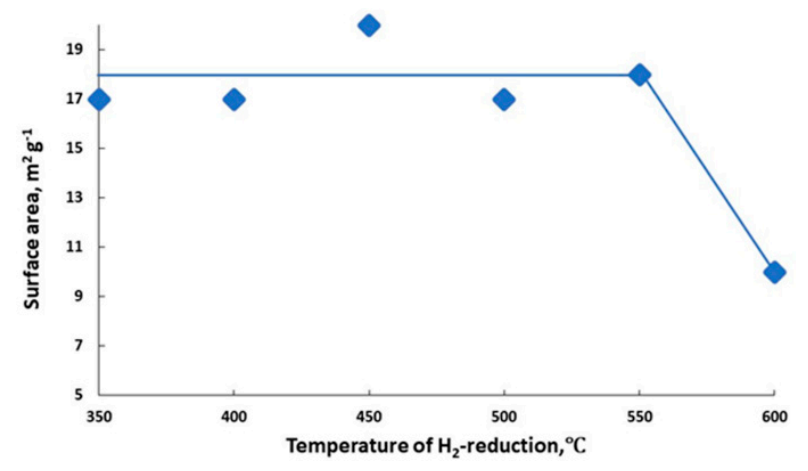

Figure 12. Effect of reduction temperature of $6 \% \mathrm{~K} / \mathrm{BaFeHAl}-30$ catalyst on its surface area.

Reducing $6 \% \mathrm{~K} / \mathrm{baFeHAl}-30$ at $550{ }^{\circ} \mathrm{C}$ increased CO capacity (Figure 8a). Thus, this catalyst was tested at this reduction temperature and oxidation temperature range of $450-550{ }^{\circ} \mathrm{C}$ where the material is resistant to sintering. CO capacity depicted in Figure 13a, based on data in Figure 13b, indicate that with increasing of oxidation temperature, the CO capacity increased from 350 to $400(\mu \mathrm{mol} / \mathrm{g})\left(\mathrm{T}_{\mathrm{r}}=550{ }^{\circ} \mathrm{C}\right)$ and from 208 to $248\left(\mu \mathrm{mol} \mathrm{g}^{-1}\right)$ at $\mathrm{T}_{\mathrm{r}}=450^{\circ} \mathrm{C}$. According to XRD and $\mathrm{N}_{2}$-adsorption data, the structure, phase composition, and crystals size of $6 \% \mathrm{~K} / \mathrm{BaFeHAl}-30$ reduced at $550{ }^{\circ} \mathrm{C}$ did not change after 
these experiments. Therefore, the amount of available active sites (oxygen vacancies) controlled by the reduction did not change during oxidation, indicating that higher oxidation temperature involves additional $\mathrm{Fe}^{2+}$ ions with lower oxidation ability.
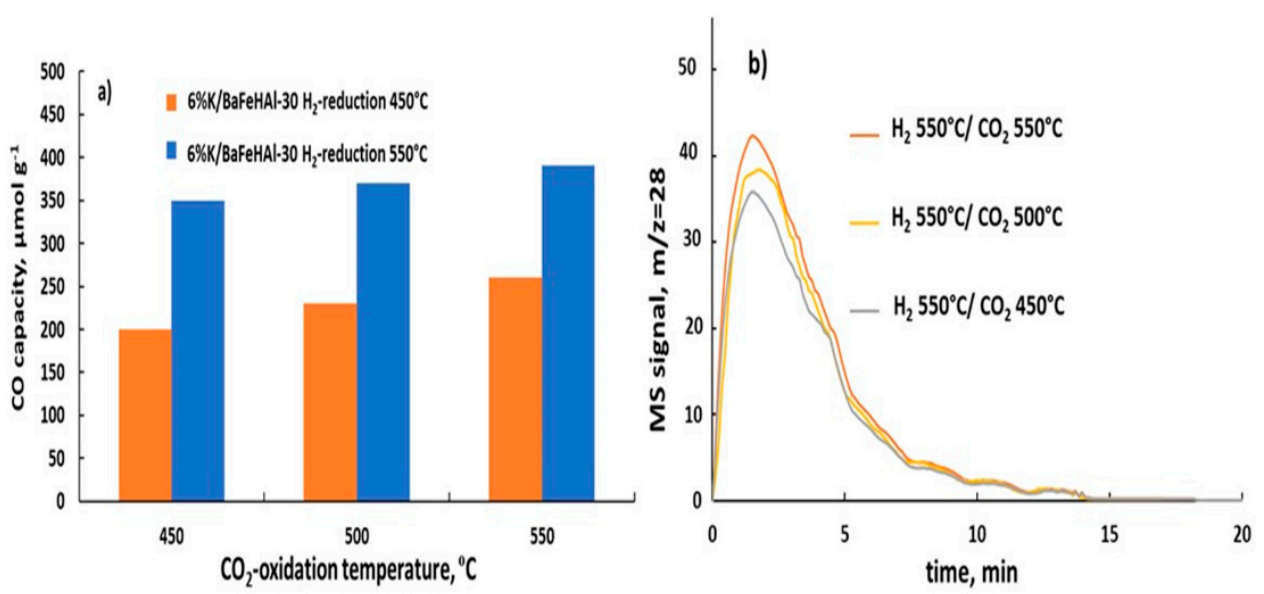

Figure 13. Effect of $\mathrm{CO}_{2}$ oxidation temperature in RWGS-CL cycles at constant $\mathrm{H}_{2}$-reduction temperature of $550{ }^{\circ} \mathrm{C}$ on the $\mathrm{CO}$ capacity of $6 \% \mathrm{~K} / \mathrm{BaFeHAl}-30$ catalyst (a) and $\mathrm{CO}$ evolution spectra (b).

At fixed $\mathrm{CO}_{2}$ concentration in the inlet gas at the $\mathrm{CO}_{2}$ oxidation step of RWGS-CL cycle, the catalysts $\mathrm{CO}_{2}$ capacity is connected with $\mathrm{CO}_{2}$ conversion at given weight hour space velocity of $\mathrm{CO}_{2}\left(\mathrm{WHSV}_{\mathrm{CO} 2}\right)$ according to Equation (1). This equation describes well the $\mathrm{CO}_{2}$ conversions calculated according to evolved CO amounts measured at $\mathrm{WHSV}_{\mathrm{CO} 2}$ of $0.4-0.9 \mathrm{~h}^{-1}$ with $6 \% \mathrm{~K} / \mathrm{BaFeHAl}-30$ catalyst at optimal isothermal RWGS-CL conditions. These data fit well to the $\mathrm{CO}_{2}$ conversions calculated according to Equation (1) assuming the constant $\mathrm{CO}$ capacity of $400 \mu \mathrm{mol} \mathrm{g}^{-1}$ (Figure 14). The maximal $\mathrm{CO}_{2}$ conversion of $14.9 \%$ was obtained at lowest tested $\mathrm{WHSV}_{\mathrm{CO} 2}=0.4 \mathrm{~h}^{-1}$. For further increase of $\mathrm{CO}_{2}$ conversion, the $\mathrm{CO}$ capacity of BaFe-hexaaluminate catalyst should be improved more. The reported data assume that this challenge may be achieved by improvement of hexaaluminate catalyst-further increasing the materials surface area and application of K-promoted high-temperature modification of $\mathrm{BaFeHF}$ as a pure phase not diluted with $\mathrm{Fe}-$, Al-oxides, and Ba-carbonate.

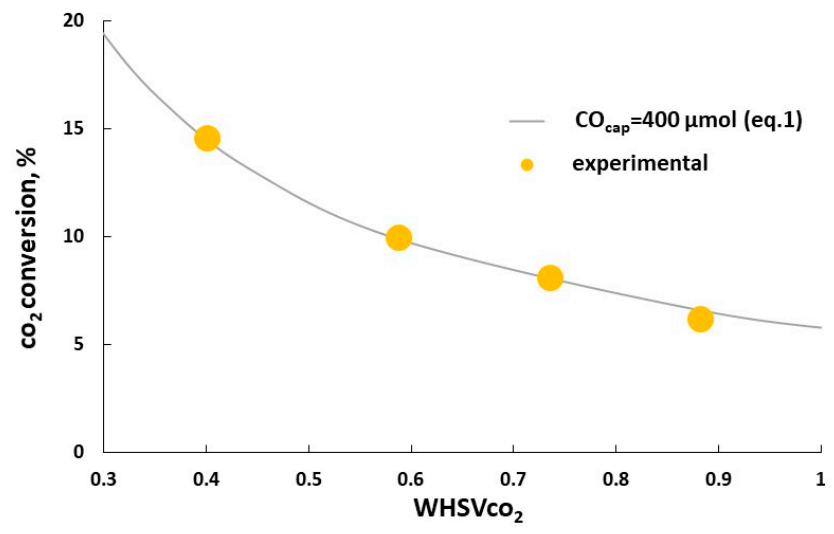

Figure 14. Effect of $\mathrm{WHSV}_{\mathrm{CO} 2}$ on $\mathrm{CO}_{2}$ conversion at inlet $\mathrm{CO}_{2}$ concentration of $5 \mathrm{vol} \%$ with $6 \% \mathrm{~K} / \mathrm{BaFeHAl}-30$ catalysts obtained in isothermal conditions: $\mathrm{T}_{\mathrm{r}}=550{ }^{\circ} \mathrm{C} ; \mathrm{T}_{\mathrm{CO}-\mathrm{ox}}=550{ }^{\circ} \mathrm{C}$.

\section{Materials and Methods}

\subsection{Catalysts Preparation}

A series of Ba-Fe-hexaaluminates with $\mathrm{Fe}$ to $\mathrm{Al}$ exchange degree of $60 \%$ denoted as $\mathrm{BaFeHAl}$ was prepared by hot co-precipitation strategy as described in [52,53]. The solution of $\mathrm{Ba}\left(\mathrm{NO}_{3}\right)_{2}$ (Alfa Aesar, 
Yehud, Israel) and $\mathrm{Fe}\left(\mathrm{NO}_{3}\right)_{3} \cdot 9 \mathrm{H}_{2} \mathrm{O}$ (Fisher Chemicals, Yehud, Israel) in hot distilled water after addition of $\mathrm{Al}\left(\mathrm{NO}_{3}\right)_{3} \cdot 9 \mathrm{H}_{2} \mathrm{O}$ (Riedel de Haën, Or Yehuda, Israel) was acidified to $\mathrm{pH} 1$ with diluted $\mathrm{HNO}_{3}$ (Gadot, Netanya, Israel). This solution was poured under vigorous stirring in excess of $\left(\mathrm{NH}_{4}\right)_{2} \mathrm{CO}_{3}$ solution heated at $60^{\circ} \mathrm{C}$. The mixed hydroxides were precipitated at $\mathrm{pH} 7.5-8.0$. After aging of obtained slurry at $60^{\circ} \mathrm{C}$ for $3 \mathrm{~h}$, filtering, washing with distilled water and in air at $110^{\circ} \mathrm{C}$ overnight, the material was calcined in air at $450{ }^{\circ} \mathrm{C}$ for $2 \mathrm{~h}$ with heating rate of $2^{\circ} \mathrm{C} \mathrm{min}^{-1}$. Finally, the catalyst was calcined in air at $1200{ }^{\circ} \mathrm{C}$ for $3 \mathrm{~h}$ with heating rate of $2{ }^{\circ} \mathrm{C} \mathrm{min}{ }^{-1}$. Potassium was deposited at the calcined catalyst by incipient wetness impregnation with aqueous solution of $\mathrm{K}_{2} \mathrm{CO}_{3}$ (the $\mathrm{K}_{2} \mathrm{CO}_{3}$ solution of suitable concentration was added to the catalyst powder at an amount corresponding to the water capacity of the material leaving the material dry) with overnight drying at $110^{\circ} \mathrm{C}$ and ending calcination at $450^{\circ} \mathrm{C}$.

The preparation of $100 \%$ substituted BaFe-hexaaluminate (hexaferrite- $\mathrm{HF}$ ) with formula $\mathrm{Ba}_{0.82}$ $\mathrm{Fe}_{10.74} \mathrm{O}_{18.1}$ was conducted by regular hot co-precipitation strategy using a different calcination procedure [53]. The dried samples were ground and then calcined by intermediate steps at 500, 700, $900,1000,1100$, and $1200{ }^{\circ} \mathrm{C}$ (heating rate, $2{ }^{\circ} \mathrm{C} \mathrm{min}{ }^{-1}$; hold at each step, $10 \mathrm{~h}$ ). This series was denoted as BaFeHF. Then a series of $\mathrm{HF}$ catalysts containing $6 \% \mathrm{~K}$ was prepared by incipient wetness, called $6 \% \mathrm{~K} / \mathrm{BaFeHF}$.

The BaFe-hexaaluminate catalysts with increased surface area and substitution of $\mathrm{Al}$ with $60 \%$ iron was prepared by carbon templating (CT) [46,47]. A hot $\left(60^{\circ} \mathrm{C}\right)$ acidic aqueous solution of Ba-Fe-Al-nitrates was added under vigorous stirring to the carbon black (Alfa Aesar, Yehud, Israel, $75 \mathrm{~m}^{2} \mathrm{~g}^{-1}$, bulk density $80-120 \mathrm{~g} \mathrm{~L}^{-1}$ ) previously hydrophilized by treatment with nitric acid. The amounts of solution and carbon black were selected to yield $45 \mathrm{wt} \%$ Ba-Fe-hexaaluminate (calculated as sum of oxides) and $55 \mathrm{wt} \%$ carbon in the dried precipitate. A large excess of aqueous $\left(\mathrm{NH}_{4}\right)_{2} \mathrm{CO}_{3}$ solution heated to $60^{\circ} \mathrm{C}$ was poured to the obtained slurry heated to $60^{\circ} \mathrm{C}$ under vigorous stirring. Then the slurry was aged for $3 \mathrm{~h}$, filtered, washed and dried by freeze-drying method (Instrument Christ Beta 1-8) for $72 \mathrm{~h}$. The dried precursors were calcined in air at $450{ }^{\circ} \mathrm{C}$ for $2 \mathrm{~h}$ $\left(2{ }^{\circ} \mathrm{C} \mathrm{min}-1\right)$ and then at $1000{ }^{\circ} \mathrm{C}\left(2{ }^{\circ} \mathrm{C} \mathrm{min}^{-1}\right)$ for $8 \mathrm{~h}$. The catalyst was designated as BaFeHAl-20. A K-promoted catalyst was then prepared by deposition of $6 \mathrm{wt} \%$ potassium as described above to this $\mathrm{CT}$ material designated as $6 \% \mathrm{~K} / \mathrm{BaFe}-\mathrm{HAl}-20$.

The carbon templating (CT) strategy $[46,47]$ was applied for preparation of BaFeHAl material with Fe-substitution degree of $60 \%$ and increased surface area. The carbon black (Alfa Aesar, Yehud, Israel $75 \mathrm{~m}^{2} \mathrm{~g}^{-1}$, bulk density $80-120 \mathrm{~g} \mathrm{~L}^{-1}$ ) hydrophilized by treatment with nitric acid at an amount corresponding to the $55 \mathrm{wt} \%$ in dried precipitate was added under vigorous stirring to a hot $\left(60^{\circ} \mathrm{C}\right)$ acidified ( $\mathrm{pH}=1)$ aqueous solution of Ba-Fe-Al-nitrates. An excess of aqueous solution of ammonium carbonate was poured under stirring to the obtained slurry at $60^{\circ} \mathrm{C}$. After aging of obtained slurry at $60^{\circ} \mathrm{C}$ for $3 \mathrm{~h}$, filtering, washing with distilled water and freeze-drying (Instrument Christ Beta 1-8) for $72 \mathrm{~h}$, the material was calcined in air at $450^{\circ} \mathrm{C}$ for $2 \mathrm{~h}$ with heating rate of $2^{\circ} \mathrm{C} \mathrm{min}-1$. Finally, the catalyst was calcined in air at $1000{ }^{\circ} \mathrm{C}$ for $8 \mathrm{~h}$ with heating rate of $2{ }^{\circ} \mathrm{C} \mathrm{min}-1$. The CT-catalyst was designated as $\mathrm{BaFeHAl}-20$. Potassium was deposited at the calcined catalyst by incipient wetness impregnation with aqueous solution of $\mathrm{K}_{2} \mathrm{CO}_{3}$ with overnight drying at $110^{\circ} \mathrm{C}$ and ending calcination at $450{ }^{\circ} \mathrm{C}$. This CT-catalyst was designated as 6\%K/BaFeHAl-20.

\subsection{Catalysts Characterization}

The $\mathrm{N}_{2}$ adsorption-desorption isotherms were recorded for all catalysts after outgassing under vacuum at $250{ }^{\circ} \mathrm{C}$ for $2 \mathrm{~h}$ using NOVA 3200e (Quantachrome, Anton Paar QuantaTec Inc., Boynton Beach, Florida, USA) instrument. The surface area, pore size, and volume of the catalysts were calculated from these isotherms using conventional BET (Brunauer-Emmett-Teller) [57] and BJH (Barrett-Joyner-Halenda) [58] methods. The catalysts chemical composition was measured by EDS (Energy Dispersive Spectroscopy) method using Quanta-200, SEM-EDAX (FEI Co., Hillsboro, OR, USA) instrument. The Panalytical Empyrean Powder Diffractometer (Cambridge, UK) equipped with position-sensitive detector $X^{\prime}$ Celerator fitted with a graphite monochromator, at $40 \mathrm{kV}$ and $30 \mathrm{~mA}$, 
was used for collecting of catalysts XRD patterns. They were analyzed with software developed by Crystal Logic Inc. (Los Angeles, CA, USA). The SBDE ZDS computer search/match program coupled with the ICDD database was used for phases identification. The Rietveld refinement of the XRD profile implementing the DBWS-9807 program (Atlanta, GA, USA) was applied for calculating of phases content in catalytic materials.

The SEM images of catalytic materials were recorded using Quanta-200, SEM-EDAX, FEI Co. instrument (Hillsboro, OR, USA). TPR measurements were performed using Chemisorption Analyzer Autochem II 2920 instrument (Micrometrics Norcross, Georgia, USA) equipped with TCD detector. TPR was done in $10 \% \mathrm{H}_{2} / \mathrm{Ar}$ flow of $5 \mathrm{~mL} \mathrm{~min}^{-1}$. The X-ray photoelectron spectrometer ESCALAB 250 apparatus (Hamamatsu City, Japan) working at ultrahigh vacuum $\left(1 \times 10^{-9}\right.$ bar) with an $\mathrm{Al} \mathrm{K \alpha}$ X-ray source and a monochromator was applied for collecting of XPS spectra. Fitting a sum of the single component lines to the experimental data by means of a non-linear least-square curve was used for identification of the spectral components of Fe signals. EX05 argon gun system performed controlled removal of surface layers. Cleaning the surface from adsorbed species before recording the XPS spectra was done using the EX05 argon gun system.

\subsection{Catalysts Testing}

The reduction-oxidation steps of $\mathrm{CO}_{2}$ conversion experiments were conducted in a quartz U-tube reactor at catalyst loadings of 0.10-0.22 g using a Chemisorption Analyzer AutoChem II 2920 instrument Norcross, Georgia, USA, Micrometrics Co. equipped with mass spectrometer Cirrus 2, MKS detector. The catalyst powder (fraction $25-180 \mu \mathrm{m}$ ) was fixed at the isothermal section of the reactor between glass-wool plugs. The inlet $\mathrm{CO}_{2}$ concentration at oxidation steps in all testing experiments was $5 \%$ vol. The detected CO MS signals $(m / z=28)$ intensities were calibrated with $\mathrm{CO} / \mathrm{He}$ mixtures of corresponding varied compositions. The RWGS-CL cycles were conducted at different temperatures in the range of $350-600{ }^{\circ} \mathrm{C}$. The sample was first reduced in $10 \% \mathrm{H}_{2} / \mathrm{Ar}$ flow of $15 \mathrm{~mL} \mathrm{~min}^{-1}$ for $20 \mathrm{~min}$. This step was followed by a $20 \mathrm{~min}$ He flushing $\left(50 \mathrm{~mL} \mathrm{~min}^{-1}\right)$ and then a catalyst oxidation step $\left(\mathrm{CO}_{2}\right.$ reduction to $\left.\mathrm{CO}\right)$ was carried out in $5 \% \mathrm{CO}_{2} / \mathrm{He}$ flow of $15 \mathrm{~mL} \mathrm{~min}^{-1}$ for $20 \mathrm{~min}$. The system was flushed with He again for $20 \mathrm{~min}$, and the cycle was repeated. First, the catalyst was stabilized in three consecutive redox cycles followed by additional three cycles of stable operation. $\mathrm{CO}$ peaks recorded in RWGS-CL isothermal cycles \# 4-6 at $450{ }^{\circ} \mathrm{C}$ with $6 \% \mathrm{~K} / \mathrm{BaFeHAl}$ catalyst are shown in Figure 15.

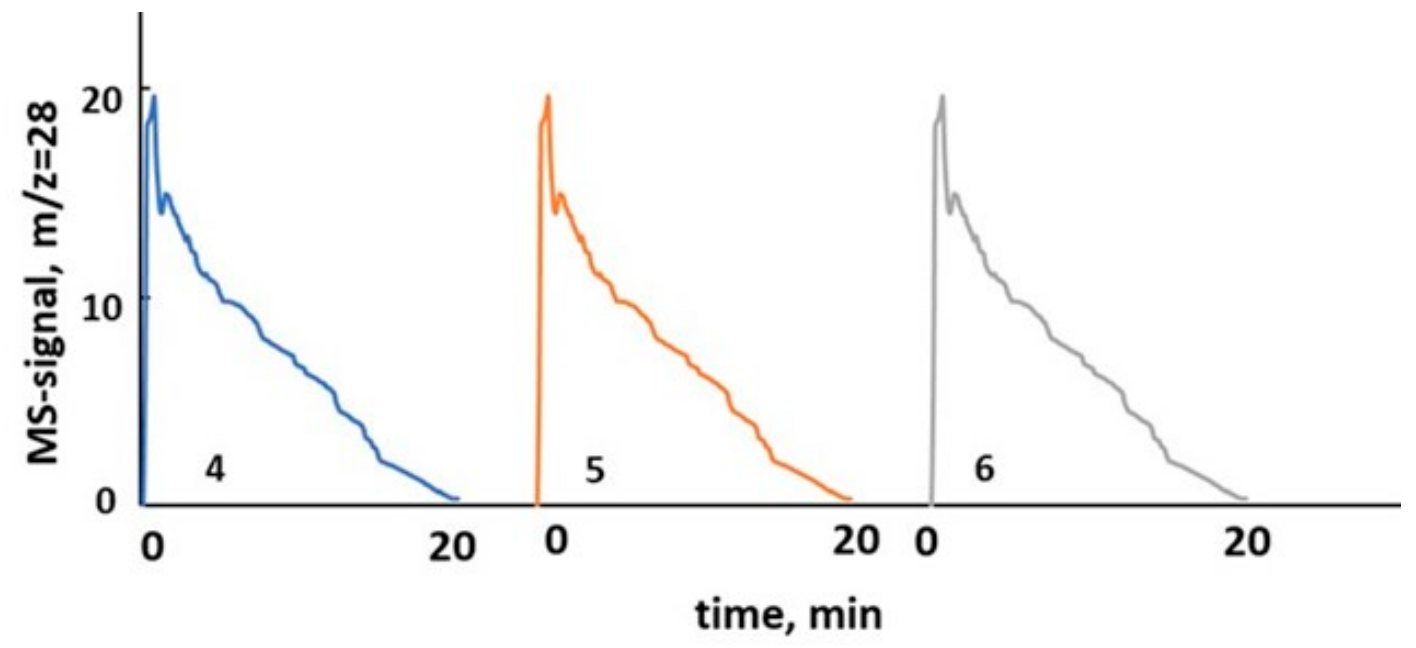

Figure 15. CO peaks recorded in isothermal RWGS-CL experiments with $6 \% \mathrm{~K} / \mathrm{BaFeHAl}$ catalyst $\left(\mathrm{T}=450{ }^{\circ} \mathrm{C}\right.$, catalyst loading $\left.0.117 \mathrm{~g}\right)$.

The catalysts performance was characterized by two parameters: $\mathrm{CO}$ capacity $\left(\mathrm{CO}_{\text {cap. }}\right)$, and $\mathrm{CO}_{2}$ conversion $\left(\mathrm{X}_{\mathrm{CO} 2}\right)$. Integration of calibrated $\mathrm{CO}$ peaks areas recorded in the oxidation step of the cycle 
yielded amount of $\mu \mathrm{mols}$ of $\mathrm{CO} / \mathrm{g}$.cat, denoted as catalysts $\mathrm{CO}$ capacity at selected testing conditions. The average $\mathrm{CO}_{2}$ conversion corresponding to the oxidation part of the RWGS-CL cycler was calculated according to Equation (1):

$$
\mathrm{X}_{\mathrm{CO} 2}=\mathrm{M}_{\mathrm{CO}} / \mathrm{M}_{\mathrm{CO} 2} \cdot 100 \%=\mathrm{CO}_{\text {cap }} \cdot \mathrm{MW}_{\mathrm{CO} 2}\left(\mathrm{WHSV}_{\mathrm{CO} 2} \cdot \mathrm{t}_{0} \cdot 1000\right)^{-1} \cdot 100 \%
$$

where, $\mathrm{M}_{\mathrm{CO}}$-amount of $\mathrm{CO}$ formed during oxidation step of the RWGS-CL cycle (mmol), $\mathrm{M}_{\mathrm{CO} 2}-$ amount of $\mathrm{CO}_{2}$ fed to reactor during oxidation step of the cycle (mmol), WHSV $\mathrm{CO}_{2}\left(\mathrm{~g} \mathrm{CO}_{2}\right.$ gcat $\left.^{-1} \mathrm{~h}^{-1}\right), \mathrm{t}_{0}$ - the length of the $\mathrm{CO}_{2}$-oxidation cycle $(\mathrm{h})$.

\section{Conclusions}

The Fe-substituted Ba-hexaaluminates are active catalysts for RWGS reaction conducted in chemical looping mode. Increasing of the degree of substitution of $\mathrm{Al}^{3+}$ for $\mathrm{Fe}^{3+}$ ions in co-precipitated Ba-hexaaluminate from $60 \%$ to $100 \%$, increased its surface area, and promotion with potassium increased the CO capacity in isothermal RWGS-CL runs at temperatures $350-450{ }^{\circ} \mathrm{C}$ where the hexaaluminate structure is stable. At higher temperatures, the fully Fe-substituted hexaaluminate- $6 \% \mathrm{~K} / \mathrm{Ba}$-hexaferrite- undergo reductive decomposition at the $\mathrm{H}_{2}$-reduction step of RWGS-CL cycle, yielding Fe-oxides, Ba-oxide, and Ba-carbonate. However, the partially Fe-substituted $6 \% \mathrm{~K} / \mathrm{BaFe}$-hexaaluminate after $\mathrm{H}_{2}$-reduction at $>450{ }^{\circ} \mathrm{C}$ is transformed to a thermally stable modification of Ba-hexaferrite that contains additional Ba-O-Fe bridges in its structure, reinforcing the connection between alternatively stacked spinel blocks. The structure and surface area of this modification of Ba-hexaferrite promoted with potassium are stable against $\mathrm{H}_{2}$ reduction up to $550{ }^{\circ} \mathrm{C}$. This allows getting higher $\mathrm{CO}_{2}$ capacity in isothermal tests at higher temperatures. The stable $6 \% \mathrm{~K} / \mathrm{BaFe}$-hexaferrite derived from $6 \% \mathrm{~K} / \mathrm{BaFe}$-hexaaluminate display higher concentration of surface oxygen vacancies compared with BaFe-hexaaluminate reflected by greater $\mathrm{Fe}^{2+} / \mathrm{Fe}^{3+}$ ratio according to XPS. Conducting of RWGS-CL cycles in isothermal mode at $550{ }^{\circ} \mathrm{C}$ where hexaferrite structure and texture is stable, further increases the materials $\mathrm{CO}$ capacity. It was demonstrated the direct connection between $\mathrm{CO}$ capacity measured in RWGS-CL experiments and calculated $\mathrm{CO}_{2}$ conversion.

Supplementary Materials: The following are available online at http://www.mdpi.com/2073-4344/10/9/1082/s1, Table S1: Atomic positions, coordinates and positions occupancies in BaFeHFco-pre material: $\mathrm{Ba}_{0.9} \mathrm{Fe}_{11.0} \mathrm{O}_{17.4}$ $(\mathrm{a}=\mathrm{b}=5.902 \AA ; \mathrm{c}=23.235 \AA)$, Table S2: Atomic positions, coordinates and positions occupancies in $\mathrm{BaFeHF}_{\mathrm{r}}$ material: $\mathrm{Ba}_{0.8} \mathrm{Fe}_{11.0} \mathrm{O}_{17.3}(\mathrm{a}=\mathrm{b}=5.801 \AA$; $\mathrm{c}=23.361 \AA)$.

Author Contributions: Conceptualization, N.U., M.V.L., M.H., and A.E.; methodology, N.U., M.V.L., M.H., and A.E.; validation, N.U.; formal analysis, N.U., M.V.L., M.H., and A.E.; investigation, N.U.; data curation, M.V.L.; writing - original draft preparation, N.U.; writing - review and editing, M.V.L. and M.H.; visualization, N.U.; supervision, M.V.L. and M.H.; funding acquisition, M.H. and M.V.L. All authors have read and agreed to the published version of the manuscript.

Funding: The Israel Ministry of Science and Technology (Grant No. 3-12386) and Blechner Foundation funded this research. This work is a part of activities of the Blechner Center of Applied Catalysis and Process Development, Chemical Engineering Department, Ben-Gurion University of the Negev in Israel.

Acknowledgments: The authors are grateful to Hagay Haun and Yaniv Gelbstein for help in disintegration of catalytic materials by high energy ball milling, and to N. Froumin for the characterization of catalytic materials by XPS method.

Conflicts of Interest: The authors declare no conflict of interest.

\section{References}

1. Zhu, M.; Ge, Q.; Zhu, X. Catalytic Reduction of $\mathrm{CO}_{2}$ to $\mathrm{CO}$ via Reverse Water Gas Shift Reaction: Recent advances in the Design of Active and Selective Supported Metal Catalysts. Trans. Tianjin Univ. 2020, 26, 172-187. [CrossRef]

2. Nielsen, D.U.; Hu, X.-M.; Daasbjerg, K.; Skrydstrup, T. Chemically and electrochemically catalyzed conversion of $\mathrm{CO}_{2}$ to $\mathrm{CO}$ with follow-up utilization to value-added chemicals. Nat. Catal. 2018, 1, 244-254. [CrossRef] 
3. Daza, Y.A.; Kuhn, J.N. $\mathrm{CO}_{2}$ conversion by reverse water gas shift catalysis: Comparison of catalysts, mechanisms and their consequences for $\mathrm{CO}_{2}$ conversion to liquid fuel. RSC Adv. 2016, 6, 49675-49691. [CrossRef]

4. Saeidi, S.; Najari, S.; Fazlollahi, F.; Nikoo, M.K.; Sefidkon, F.; Klemeš, J.J.; Baxter, L.L. Mechanisms and kinetics of $\mathrm{CO}_{2}$ hydrogenation to value-added products: A detailed review on current status and future trends. Renew. Sust. Energy Rev. 2017, 80, 1292-1311. [CrossRef]

5. Kaiser, P.; Unde, R.B.; Kern, C.; Jess, A. Production of Liquid Hydrocarbons with $\mathrm{CO}_{2}$ as Carbon Source based on Reverse Water-Gas Shift and Fischer-Tropsch Synthesis. Chem. Ing. Tech. 2013, 85, 489-499. [CrossRef]

6. Vázquez, F.V.; Pfeifer, P.; Lehtonen, J.; Piermartini, P.; Simell, P.; Alopaeus, V. Catalyst Screening and Kinetic Modeling for CO Production by High Pressure and Temperature Reverse Water Gas Shift for Fischer-Tropsch Applications. Ind. Eng. Chem. Res. 2017, 56, 13262-13272. [CrossRef]

7. Lyngfelt, A. Oxygen Carriers for Chemical Looping Combustion-4000 h of Operational Experience. Oil Gas Sci. Technol. 2011, 66, 161-172. [CrossRef]

8. Bayham, S.; McGiveron, O.; Tong, A.; Chung, E.; Kathe, M.; Wang, D.W.; Zeng, L.; Fan, L.S. Parametric and dynamic studies of an iron-based 25-kWth coal direct chemical looping unit using subbituminous coal. Appl. Energy 2015, 145, 354-363. [CrossRef]

9. Tong, A.; Bayham, S.; Kathe, M.V.; Zeng, L.; Luo, S.; Fan, L.-S. Iron-based syngas chemical Looping process and coal-direct chemical looping process development at Ohio State University. Appl. Energy 2014, 113, 1836-1845. [CrossRef]

10. Galvita, V.; Hempel, T.; Lorenz, H.; Rihko-Struckmann, L.K.; Sundmacher, K. Deactivation of modified iron oxide materials in the cyclic water gas shift process for $\mathrm{CO}$-free hydrogen production. Ind. Eng. Chem. Res. 2008, 47, 303-310. [CrossRef]

11. Datta, P.; Rihko-Struckmann, L.K.; Sundmacher, K. Influence of molybdenum on the stability of iron oxide materials for hydrogen production with cyclic water gas shift process. Mater. Chem. Phys. 2011, 129, 1089-1095. [CrossRef]

12. Galvita, V.V.; Poelman, H.; Bliznuk, V.; Detavernier, C.; Marin, G.B. $\mathrm{CeO}_{2}-\mathrm{Modified} \mathrm{Fe}_{2} \mathrm{O}_{3}$ for $\mathrm{CO}_{2}$ Utilization via Chemical Looping. Ind. Eng. Chem. Res. 2013, 52, 8416-8426. [CrossRef]

13. Meledina, M.; Turner, S.; Galvita, V.V.; Poelman, H.; Marin, G.B.; Van Tendeloo, G. Local environment of Fe dopants in nanoscale Fe: $\mathrm{CeO}_{2-x}$ oxygen storage material. Nanoscale 2015, 7, 3196-3204. [CrossRef] [PubMed]

14. Mattisson, T.; Lyngfelt, A.; Cho, P. The use of iron oxide as an oxygen carrier in chemical-looping combustion of methane with inherent separation of $\mathrm{CO}_{2}$. Fuel 2001, 80, 1953-1962. [CrossRef]

15. Galvita, V.V.; Poelman, H.; Marin, G.B. Hydrogen Production from Methane and Carbon Dioxide by Catalyst-Assisted Chemical Looping. Top. Catal. 2011, 54, 907-913. [CrossRef]

16. Corbella, B.M.; Palacios, J.M. Titania-supported iron oxide as oxygen carrier for chemical-looping combustion of methane. Fuel 2004, 86, 113-122. [CrossRef]

17. Rihko-Struckmann, L.K.; Datta, P.; Wenzel, M.; Sundmacher, K.; Dharanipragada, N.V.R.A.; Poelman, H.; Galvita, V.V.; Marin, G.B. Hydrogen and Carbon Monoxide Production by Chemical Looping over Iron-Aluminum Oxides. Energy Technol. 2016, 4, 304-313. [CrossRef]

18. Daza, Y.A.; Kent, R.A.; Yung, M.M.; Kuhn, J.N. Carbon Dioxide Conversion by Reverse Water-Gas Shift Chemical Looping on Perovskite-Type Oxides. Ind. Eng. Chem. Res. 2014, 53, 5828-5837. [CrossRef]

19. Daza, Y.A.; Maiti, D.; Kent, R.A.; Bhethanabotla, V.R.; Kuhn, J.N. Isothermal reverse water gas shift chemical looping on $\mathrm{La}_{0.75} \mathrm{Sr}_{0.25} \mathrm{Co}_{(1-\mathrm{y})} \mathrm{Fe}_{\mathrm{y}} \mathrm{O}_{3}$ perovskite-type oxides. Catal. Today 2015, 258, 691-698.

20. Hare, B.J.; Maiti, D.; Daza, Y.A.; Bhethanabotla, V.R.; Kuhn, J.N. Enhanced $\mathrm{CO}_{2}$ Conversion to $\mathrm{CO}$ by Silica-Supported Perovskite Oxides at Low Temperatures. ACS Catal. 2018, 8, 3021-3029. [CrossRef]

21. Maiti, D.; Hare, B.J.; Daza, Y.A.; Ramos, A.E.; Kuhn, J.N.; Bhethanabotla, V.R. Earth abundant perovskite oxides for low temperature $\mathrm{CO}_{2}$ conversion. Energy Environ. Sci. 2018, 11, 648-659. [CrossRef]

22. Ramos, A.E.; Maiti, D.; Daza, Y.A.; Kuhn, J.N.; Bhethanabotla, V.R. Co, Fe, and Mn in La-perovskite oxides for low temperature thermochemical $\mathrm{CO}_{2}$ conversion. Catal. Today 2019, 338, 52-59. [CrossRef]

23. Hare, B.J.; Maiti, D.; Meier, A.J.; Bhethanabotla, V.R.; Kuhn, J.N. CO 2 Conversion Performance of Perovskite Oxides Designed with Abundant Metals. Ind. Eng. Chem. Res. 2019, 58, 12551-12560. [CrossRef]

24. Hare, B.J.; Maiti, D.; Ramani, S.; Ramos, A.E.; Bhethanabotla, V.R.; Kuhn, J.N. Thermochemical conversion of carbon dioxide by reverse water-gas shift chemical looping using supported perovskite oxides. Catal. Today 2019, 323, 225-232. [CrossRef] 
25. Hu, J.; Galvita, V.V.; Poelman, H.; Detavernier, C.; Marin, G.B. A core-shell structured $\mathrm{Fe}_{2} \mathrm{O}_{3} / \mathrm{ZrO}_{2} @ \mathrm{ZrO}_{2}$ nanomaterial with enhanced redox activity and stability for $\mathrm{CO}_{2}$ conversion. J. $\mathrm{CO}_{2}$ Util. 2017, 17, $20-31$. [CrossRef]

26. Wenzel, M.; Dharanipragada, N.V.R.A.; Galvita, V.V.; Poelman, H.; Marin, G.B.; Rihko-Struckmann, L.; Sundmacher, K. CO production from $\mathrm{CO}_{2}$ via reverse-water-gas shift reaction performed in a chemical looping mode: Kinetics on modified iron oxide. J. $\mathrm{CO}_{2}$ Util. 2017, 17, 60-68. [CrossRef]

27. Dharanipragada, N.V.R.A.; Meledina, M.; Galvita, V.V.; Poelman, H.; Turner, S.; Van Tendeloo, G.; Detavernier, C.; Marin, G.B. Deactivation Study of $\mathrm{Fe}_{2} \mathrm{O}_{3}-\mathrm{CeO}_{2}$ during Redox Cycles for CO Production from $\mathrm{CO}_{2}$. Ind. Eng. Chem. Res. 2016, 55, 5911-5922. [CrossRef]

28. Hu, J.; Buelens, L.; Theofanidis, S.-A.; Galvita, V.V.; Poelman, H.; Marin, G.B. $\mathrm{CO}_{2}$ conversion to CO by auto-thermal catalyst-assisted chemical looping. J. $\mathrm{CO}_{2}$ Util. 2016, 16, 8-16. [CrossRef]

29. Galvita, V.V.; Poelman, H.; Detavernier, C.; Marin, G.B. Catalyst-assisted chemical looping for $\mathrm{CO}_{2}$ conversion to CO. Appl. Catal. B Environ. 2015, 164, 184-191. [CrossRef]

30. Ma, L.; Qiu, Y.; Li, M.; Cui, D.; Zhang, S.; Zeng, D.; Xiao, R. Spinel-Structured Ternary Ferrites as Effective Agents for Chemical Looping $\mathrm{CO}_{2}$ Splitting. Ind. Eng. Chem. Res. 2020, 59, 6924-6930. [CrossRef]

31. Kim, S.; Lee, D.; Lee, J.Y.; Eom, H.; Lee, H.J.; Cho, I.; Lee, K. Catalytic combustion of methane in simulated PSA offgas over Mn-substituted La-Sr-hexaaluminate $\left(\mathrm{La}_{x} \mathrm{Sr}_{1-\mathrm{x}} \mathrm{MnAl}_{11} \mathrm{O}_{19}\right)$. J. Mol. Catal. A Chem. 2011, 335, 60-64. [CrossRef]

32. Forzatti, P.; Groppi, G. Catalytic combustion for the production of energy. Catal. Today 1999, 54, $165-180$. [CrossRef]

33. Huang, F.; Wang, X.; Li, L.; Liu, X.; Xu, J.; Huang, C.; Zhang, T. Effect of magnesium substitution into Fe-based La-hexaaluminates on the activity for $\mathrm{CH}_{4}$ catalytic combustion. Catal. Sci. Tech. 2016, 6, 7860-7867. [CrossRef]

34. Sidwell, R.W.; Zhu, H.; Kee, R.J.; Wickham, D.T. Catalytic combustion of premixed methane-in-air on a high-temperature hexaaluminate stagnation surface. Combust. Flame 2003, 134, 55-66. [CrossRef]

35. Chu, W.; Yang, W.; Lin, L. Selective Oxidation of Methane to Syngas over NiO/Barium Hexaaluminate. Catal. Lett. 2001, 74, 139-144. [CrossRef]

36. Chu, W.; Yang, W.; Lin, L. The partial oxidation of methane to syngas over the nickel-modified hexaaluminate catalysts $\mathrm{BaNi}_{\mathrm{y}} \mathrm{Al}_{12-\mathrm{y}} \mathrm{O}_{19-\delta}$. Appl. Catal, A Gener. 2002, 235, 39-45. [CrossRef]

37. Liu, Y.; Xu, Z.; Cheng, T.; Zhou, G.; Wang, J.; Li, W.; Bi, Y.; Zhen, K. Studies on Carbon Deposition on Hexaaluminate $\mathrm{LaNiAl}_{11} \mathrm{O}_{19}$ Catalysts during $\mathrm{CO}_{2}$ Reforming of Methane. Kinet. Catal. 2002, 43, $522-527$. [CrossRef]

38. Ikkour, K.; Sellam, D.; Kiennemann, A.; Tezkratt, S.; Cherifi, O. Activity of Ni Substituted Ca-La-hexaaluminate Catalyst in Dry Reforming of Methane. Catal. Lett. 2009, 132, 213-217. [CrossRef]

39. Kim, H.; Lee, S.J.; Song, K.S. Performance of Ni catalyst supported on La-hexaaluminate in $\mathrm{CO}_{2}$ reforming of $\mathrm{CH}_{4}$. Korean J. Chem. Eng. 2007, 24, 477-480. [CrossRef]

40. Gardner, T.H.; Spivey, J.J.; Kugler, E.L.; Campos, A.; Hissam, J.C.; Roy, A.D. Structural Characterization of Ni-Substituted Hexaaluminate Catalysts Using EXAFS, XANES, XPS, XRD, and TPR. J. Phys. Chem. C 2010, 114, 7888-7894. [CrossRef]

41. Iyi, N.; Takekawa, S.; Kimura, S. Crystal Chemistry of Hexaaluminates: $\beta$-Alumina and Magnetoplumbite Structures. J. Solid State Chem. 1989, 83, 8-19. [CrossRef]

42. Zhang, Y.; Wang, X.; Zhu, Y.; Liu, X.; Zhang, T. Thermal Evolution Crystal Structure and Fe Crystallographic Sites in $\mathrm{LaFe}_{\mathrm{x}} \mathrm{Al}_{12-\mathrm{x}} \mathrm{O}_{19}$ Hexaaluminates. J. Phys. Chem. C 2014, 118, 10792-10804. [CrossRef]

43. Santiago, M.; Pérez-Ramírez, J. Decomposition of $\mathrm{N}_{2} \mathrm{O}$ over Hexaaluminate Catalysts. Environ. Sci. Technol. 2007, 41, 1704-1709. [CrossRef] [PubMed]

44. Zwinkels, M.F.; Järås, S.G.; Menon, P.G.; Griffin, T.A. Catalytic Materials for High-Temperature Combustion. Catal. Rev. Sci. Eng. 1993, 35, 319-358. [CrossRef]

45. Laassiri, S.; Duprez, D.; Royer, S.; Alamdari, H. Solvent free synthesis of nanocrystalline Hexaaluminate type mixed oxides with high specific surface areas for CO oxidation reaction. Catal. Sci. Technol. 2011, 1, 1124-1127. [CrossRef]

46. Gao, J.; Jia, C.; Zhang, M.; Gu, F.; Xu, G.; Zhong, Z.; Su, F. Template preparation of high-surface-area barium hexaaluminate as nickel catalyst support for improved CO methanation. RSC Adv. 2013, 3, 18156-18163. [CrossRef] 
47. Santiago, M.; Groen, J.C.; Pérez-Ramírez, J. Carbon-templated hexaaluminates with enhanced surface area and catalytic performance. J. Catal. 2008, 257, 152-162. [CrossRef]

48. Mleczko, L.; Duff, D.G.; Karpenko, A.; Kockrick, E.; Gepret, V.; Tulke, A.; Vichmann, D. Method for reducing carbon dioxide at high temperatures on mixed metal oxide catalysts in the form of hexaaluminates. PCT International Application WO 2013135656, 19 September 2013.

49. Utsis, N.; Vidruk-Nehemya, R.; Landau, M.V.; Herskowitz, M. Novel bifunctional catalysts based on crystalline multi-oxide matrices containing iron ions for $\mathrm{CO}_{2}$ hydrogenation to liquid fuels and chemicals. Faraday Discuss. 2016, 188, 545-563. [CrossRef]

50. Utsis, N.; Landau, M.V.; Erenburg, A.; Vidruk-Nehemya, R.; Herskowitz, M. Performance of Reverse Water Gas Shift on Coprecipitated and C-Templated BaFe-Hexaaluminate: The Effect of Fe Loading, Texture, and Promotion with K. ChemCatChem 2018, 10, 3795-3805. [CrossRef]

51. Landau, M.V.; Meiri, N.; Utsis, N.; Vidruk-Nehemya, R.; Herskowitz, M. Conversion of $\mathrm{CO}_{2}, \mathrm{CO}_{\text {, and } \mathrm{H}_{2}}$ in $\mathrm{CO}_{2}$ Hydrogenation to Fungible Liquid Fuels on Fe-Based Catalysts. Ind. Eng. Chem. Res. 2017, 56, 13334-13355. [CrossRef]

52. Groppi, G.; Bellotto, M.; Cristiam, C.; Forzatti, P.; Villa, P. Preparation and characterization of hexaaluminate-based materials for catalytic combustion. Appl. Catal. A General 1993, 104, 101-108. [CrossRef]

53. Groppi, G.; Cristiani, C.; Forzatti, P. BaFeXAl $(12-x) \mathrm{O}_{19}$ system for high-temperature catalytic combustion: Physico-chemical characterization and catalytic activity. J. Catal. 1997, 168, 95-103. [CrossRef]

54. Artizzu-Duart, P.; Millet, J.; Guilhaume, N.; Garbowski, E.; Primet, M. Catalytic combustion of methane on substituted barium hexaaluminates. Catal. Today 2000, 59, 163-177. [CrossRef]

55. Sandiumenge, F.; Gali, S.; Rodriguez, J. X-ray profile analysis of cation substitution in $\mathrm{SrAl}_{\mathrm{x}} \mathrm{Fe}_{12-\mathrm{x}} \mathrm{O}_{19}$ solid solution. Mater. Res. Bull. 1988, 23, 685-692. [CrossRef]

56. Amoyal, M.; Vidruk-Nehemya, R.; Landau, M.V.; Herskowitz, M. Effect of potassium on the active phases of Fe catalysts for carbon dioxide conversion to liquid fuels through hydrogenation. J. Catal. 2017, 348, $29-39$. [CrossRef]

57. Brunauer, S.; Emmett, P.H.; Teller, E.J. Adsorption of Gases in Multimolecular Layers. Am. Chem. Soc. 1938, 60, 309-319. [CrossRef]

58. Barrett, E.P.; Joyner, L.G.; Halenda, P.P. The determination of pore volume and area distributions in porous substances. I. Computations from nitrogen isotherms. J. Am. Chem. Soc. 1951, 73, 373-380.

(C) 2020 by the authors. Licensee MDPI, Basel, Switzerland. This article is an open access article distributed under the terms and conditions of the Creative Commons Attribution (CC BY) license (http://creativecommons.org/licenses/by/4.0/). 